\title{
ON THE HARDENING OF PHARAOH'S HEART ${ }^{1}$
}

\author{
[A NEW TRANSLATION WITH INTRODUCTION AND NOTES]
}

\author{
by
}

Bryn R. Rees $\dagger$

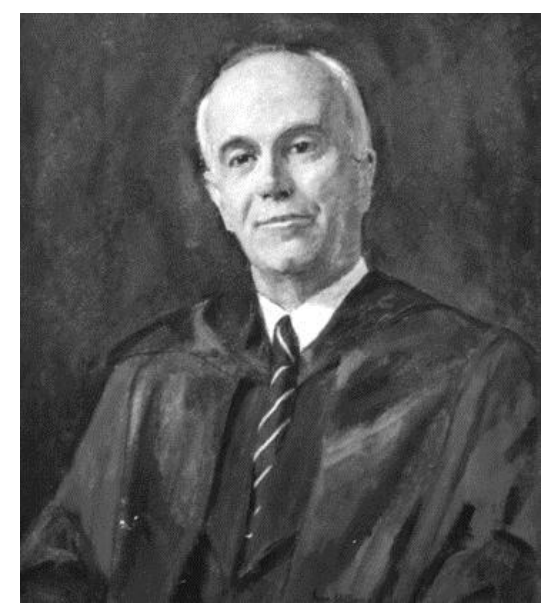

[edited by Nicholas Baker-Brian and Josef Lössl]

[Editors' Note:

Brinley (Bryn) Roderick Rees (1919-2004) was Professor of Greek at the University of Wales, Cardiff College, from 1958 to 1970, and at the University of Birmingham

\footnotetext{
${ }^{1}$ De induratione cordis Pharaonis et de uasis honoris et contumeliae ('On the Hardening of Pharaoh's Heart and on Vessels of Honour and Dishonour') or De induratione cordis Pharaonis et de aliis quattuor quaestionibus ('On the Hardening of Pharaoh's Heart and on Four Other Questions'); PLS 1, 1506-39; CPL 729. In this book it will be referred to as the De induratione.

Bryn R. Rees, “On the Hardening of Pharaoh's Heart,” in: Journal for Late Antique Religion and Culture 6 (2012) 1-54; ISSN: 1754-517X; Website: http://www.cardiff.ac.uk/clarc/jlarc
} 
from 1970 to 1975 . He then was Principal at the University of Wales, Lampeter, St. David's College, before retiring in 1980. An eminent papyrologist - P. Hermopolis, edited by B. R. Rees, is frequently referred to as P.Herm.Rees - Brynley Rees also counted Pelagius and Pelagianism among his main research interests. He was the author of Pelagius. A Reluctant Heretic (1988) and of Pelagius. Life and Letters (1991, reprint. 2004).

During the last years of his life Professor Rees was working on translations, with introductions and notes, of a set of texts which shed light on a particular aspect of the origins and early development of the Pelagian controversy, namely the exegesis of Romans 9 with its main theme of God's justice in the light of predestination. Professor Rees seems to have intended to publish these texts as a group, although his handwritten manuscript does not contain a general introduction or a title for the intended book.

The texts include a Pelagian work entitled 'On the Hardening of Pharaoh's Heart' (De induratione cordis Pharaonis) and excerpts from two works by Augustine, 'An Explanation of Some Topics in the Epistle to the Romans' (Expositio quarundam propositionum in epistola ad Romanos) and 'On Various Questions to Simplicianus' (De diversis quaestionibus ad Simplicianum), and from Pelagius' 'Commentary on Romans'.

While the publication of Professor Rees' work in its entirety is a desideratum and will eventually shed further light on this debate in late-antique biblical exegesis as well as on the question of the authorship of the De induratione, the editors of the present text, with the permission of Mrs. Zena Rees, present Professor Rees' introduction to and translation of the De induratione on its own, not as part of the intended whole work on the exegesis of Romans 9, but as a rare but significant contribution to research on this rather obscure Pelagian work, which clearly deserves more attention than it has hitherto received.

What follows is transcribed from Professor Rees' autograph. Citations and styles have been adapted, and in some rare cases notes have been added in square brackets. However, it is not the editors' intention to present a study on the De induratione at the current level of scholarship, which obviously has progressed since Professor Rees last worked on this material, but merely to make Professor Rees' contribution available in its own right.

The editors would like to thank Mrs. Zena Rees for her generous support in making the autograph available for transcription and in giving permission to publish the text.]

Bryn R. Rees, “On the Hardening of Pharaoh's Heart,” in: Journal for Late Antique Religion and Culture 6 (2012) 1-54; ISSN: 1754-517X; Website: http://www.cardiff.ac.uk/clarc/jlarc 


\section{INTRODUCTION}

This important but problematic treatise was unearthed in 1903 in the Library of Metz by Dom Germain Morin, who brought it to the attention of other scholars in $1909 .^{2}$ Its existence had previously been mentioned as long ago as A.D. 850, when Hincmar, Archbishop of Reims, is said to have quoted from it in the course of his famous controversy with the maverick Gottschalk in a treatise on predestination and free will. $^{3}$ At the time Hincmar believed it to be a work by Jerome, among whose apocryphal writings it was found, and excerpts from it also appeared in a treatise of his in which they are described as being from 'the book of the blessed Jerome entitled De obduratione cordis Pharaonis et de praescitis et praedestinatis' - that is, 'On the Hardening of Pharaoh's Heart and on Foreknowledge and Predestination'. But if Jerome did indeed write a treatise on such a topic or, at least, had done more than touch upon it in one of his numerous works, as he himself claims to have done, ${ }^{5}$ it cannot possibly have been this treatise, which is Pelagian through and through.

The Metz manuscript was found to be incomplete but the indefatigable Morin discovered that there were five others in existence and proceeded to transcribe them as well; four were in England - at Cambridge, Eton, Oxford and Worcester - and the fifth in the Vatican, and they ranged from the eleventh to the fifteenth century. Along with the Metz MS and a seventh, which turned up at Leiden and was dated to the tenth century, these formed the basis of Morin's edition, which he supplied with an apparatus criticus, intending to publish it as soon as possible. ${ }^{6}$ His plans were thwarted by the outbreak of the First World War, during which the proofs of his edition were destroyed in Belgium, presumably by fire. Later he was able to reassemble his text of the first thirty-five chapters and - not without some reluctance

2 G. Morin, 'Un traité pélagien inédit du commencement du cinquième siècle,' in: Revue Bénédictine 26, 1909, 163-188.

3 'And he maintains that you were so misled by the the style of a certain book which is said to be Jerome's "On the Hardening of Pharaoh's Heart" that you stated that God did not harden Pharaoh's heart but (merely) allowed it to be hardened', a quotation from a letter of Raban Maur, written in 850 (PL 112, 1522B) and reporting a remark of ille Corbegensis monachus, 'that monk of Corbie', viz. Ratramnus, who wrote his De praedestinatione in defence of double predestination; Morin, art. cit. 165.

${ }^{4}$ Cf. W. Grundlach, 'Zwei Schriften des Erzbischofs Hinkmar von Reims,' II, in: Zeitschrift für Kirchengeschichte 10,1889, 258-310. There is also a reference to the treatise in 'A Book on Three Letters', ca. 855, probably written by Florus of Lyon, who supported Gottschalk in the controversy on double predestination (PL 121, 1052B); Morin, art. cit. 163f.; F. G. Nuvolone, 'Problèmes d'une nouvelle édition du De induratione Cordis Pharaonis attribué à Pélage,' in: Revue des études augustiniennes 26, 1980, 105.

${ }^{5}$ See PL 39, 1786, in the $22^{\text {nd }}$ sermon in an Appendix to Augustine's works; Morin, art. cit. 164.

${ }^{6}$ See Nuvolone, 1980, 112.

Bryn R. Rees, “On the Hardening of Pharaoh's Heart,” in: Journal for Late Antique Religion and Culture 6 (2012) 1-54; ISSN: 1754-517X; Website: http://www.cardiff.ac.uk/clarc/jlarc 
- sent it to Georges de Plinval in 1932, following it up in 1934 with a transcript of the Eton manuscript's version of the missing chapters made by M. R. James. ${ }^{7}$ Plinval then began work on his own edition, based substantially on Morin's, and published it in 1947 with suitable acknowledgement of his indebtedness to the latter. ${ }^{8}$ But Morin had died in the previous year and so did not live to see the finished projects of his labours, begun over thirty years earlier. Perhaps it was just as well, since Plinval, though endowed with a fertile imagination and an enviable talent for synthesis, was clearly no editor, and others who have since taken up the burden of producing a critical edition have either put it down again or postponed the task.

However that may be, Morin had given the enterprise a good start on fairly solid foundations. The manuscripts which he used were, as we have said, six in number in the following order:

$$
\begin{aligned}
& \mathrm{M}=\text { Metz Municipal Library } 1172\left(11^{\text {th }} \text { century }\right){ }^{9} \\
& \left.\mathrm{E}=\text { Eton College Library } 21 \text { (mid- } 12^{\text {th }} \text { century }\right) ; \\
& \mathrm{C}=\text { Cambridge, Emmanuel College MS } 56\left(15^{\text {th }} \text { century }\right) ; \\
& \mathrm{W}=\text { Worcester Cathedral Library F } 114\left(15^{\text {th }} \text { century }\right) ; \\
& \mathrm{O}=\text { Oxford, Bodleian Library } 757\left(15^{\text {th }} \text { century }\right) ; \\
& \mathrm{B}=\text { Rome, Vatican Library, Barberini Latini } 552\left(15^{\text {th }} \text { century }\right) .{ }^{10}
\end{aligned}
$$

He was also able to use extracts quoted by Archbishop Hincmar in his treatise on predestination and later to be designated as L by Nuvolone. ${ }^{11}$ At the outset Plinval lists all six MSS used by Morin and also includes in his apparatus criticus one reference to $\mathrm{H}$ (as Hincmar); but, in fact, he does not seem to have used - or seen? -

\footnotetext{
${ }^{7}$ Ibid. 108.

${ }^{8}$ G. de Plinval, Essai sur le style et la langue de Pélage, Fribourg 1947, 120-203.

${ }^{9}$ It ends with 'ut in eo', 'so that in him' (in c. 54). There is also a lacuna from c. 10 to c. 35 , and so the MS as a whole contains barely a third of the original text, and even that is very defective.

${ }^{10}$ I have listed these MSS in the same order as Morin. He and Plinval saw little merit in all except $\mathrm{E}$, and that had been carefully but mistakenly corrected in order to reduce the archaisms in it; $\mathrm{C}$ they found very faulty and the work of a copyist who did not understand the text which he was copying; W is readable and packed with abbreviations, and principally interesting for the marginal comments drawing the reader's attention to the most obviously Pelagian features; O is very similar to W but not so well written and 'bristled' with abbreviations; $\mathrm{B}$ is close to $\mathrm{M}$ but marred by many inadvertent omissions. (I am summarising Morin here.) I have been able to obtain and examine only the MSS discovered in England in photocopy, microfilm or microfiche, and except for a few places, my readings support those of Nuvolone.

${ }^{11}$ Nuvolone 1980, 112.

Bryn R. Rees, “On the Hardening of Pharaoh's Heart,” in: Journal for Late Antique Religion and Culture 6 (2012) 1-54; ISSN: 1754-517X; Website: http://www.cardiff.ac.uk/clarc/jlarc
} 
$\mathrm{O}$ or $\mathrm{W}$ nor does he include them in the table of MSS at the end of his introduction to the text, ${ }^{12}$ and he appears to have cited V (=B) as R on two occasions. ${ }^{13} 14$

Plinval considered $\mathrm{E}$ to be 'in all respects the most satisfactory' of the MSS available to him a the time. ${ }^{15}$ It had served as the basis of Morin's edition, and he left it unchanged in all except minor particulars; for example, he replaced the division into two books, found in the other MSS but not in E, by one into fifty-five small chapters, each preceded by an appropriate subtitle in his French translation for the sake of clarity and easy reference. He also made improvements in the punctuation, corrected the most serious editorial errors, and eliminated solecisms, misspellings and other copyists' mistakes. But many of his alterations of the text are either not indicated or intelligible only with difficulty, and new errors, mainly of copying or printing, have been introduced. Some of these are repeated by Hamman in his 'edition' in the first supplement to Migne's Patrologia Latina, ${ }^{16}$ and new ones also appear there, as do some 'happy corrections'. ${ }^{17}$ It is to be hoped that Nuvolone will be able to find time to publish his text ${ }^{18}$ and apparatus criticus, especially as so many of the alternative readings disclosed in his article would remove obscurities in the text and clear the way for a better understanding of it. In his fascinating résumé of the problems of producing an edition of the De induratione, he lists C, E. L $(=\mathrm{H}), \mathrm{M}, \mathrm{O}, \mathrm{V}$ and $\mathrm{W}$ in that order as well as a MS announced in 1908 but unknown to Morin and Plinval, B for Bologna (fifteenth century) and two others, W (from Cesena, fifteenth century) and S (Sotheby, c. 1450, listed in Sotheby's catalogue of 19 June 1979); ${ }^{19}$ he has also collated three editions - Morin's (Mo) and Plinval's (P1) of the De induratione and Grundlach's of Hincmar. Six of the nine MSS have their provenance in England ${ }^{20}$ and are dated from the eleventh to the fifteenth century, the remainder come from the continent and are fifteenth century. Nuvolone points out the direct manuscript tradition is therefore extremely limited and geographically restricted and is not old,

12 Plinval 1947, 120.

${ }^{13}$ Ibid. 134, omitting, of course, $\mathrm{O}$ and $\mathrm{W}$.

14 Ibid. 149.

15 Ibid. 120.

${ }^{16}$ This cannot be described as a critical edition, and Hamman clearly did not intend it to be, as there is no apparatus criticus. But the same is true of all the 'editions' contained in PLS 1.

${ }^{17}$ Nuvolone 1980, 106.

${ }^{18}$ Notified in 1986 in his and [Aimé] Solignac's indispensable article on 'Pelage et Pelagianisme', Dictionnaire de Spiritualite, [vol. 12/2,] 1986, 2920.

${ }^{19}$ Op. cit. 113 and see n. 20.

${ }^{20}$ Viz. E, C, W, O, S and M, which Nuvolone has now shown to be of English, not continental provenance; op. cit. 108, n. 7. It is interesting to see Morin drawing attention to this dependence on English MSS copied or, at least, found in 'country of origin and the historic land of Pelagianism' (183 n.). This fact is possibly even more significant in the present connection.

Bryn R. Rees, “On the Hardening of Pharaoh's Heart,” in: Journal for Late Antique Religion and Culture 6 (2012) 1-54; ISSN: 1754-517X; Website: http://www.cardiff.ac.uk/clarc/jlarc 
the Hincmar excerpts perhaps giving the only hint of an earlier tradition. ${ }^{21}$ While appreciating the virtue of $\mathrm{E}$, he is not minded to place too much reliance on it, certainly far less than did Morin and Plinval; he prefers to follow a via media whenever possible and warns us of the danger of succumbing to the temptation of correcting the numerous eccentricities of the text independently of the MSS themselves. I have, however, ventured to amend Plinval's text where Nuvolone's corrections and my own readings seem to offer a better and more reliable sense.

The author of the De induratione begins in the conventional manner, so familiar to readers of contemporary treatises and letters, by protesting his complete unsuitability to perform the task with which his correspondent has presented him, that is, of providing a discussion paper on the theme of 'The hardening of Pharaoh's heart and honourable and dishonourable vessels': his correspondent, he submits, is far too expert in such matters to require the advice of a man of only moderate intelligence like himself who is backing in the necessary skills, and, furthermore, the friend who has delivered the message is himself a formidable interrogator. He feels, therefore, that he is entitled to plead with them to excuse any inadequacies in his response to their request and to take personal responsibility for them. His reply will examine five related topics: the first is the text in the Decalogue which states 'I shall visit the sins of the fathers upon the sons to the third and fourth generation of them that hate me'; the second concerns Pharaoh; the third Esau and Jacob; the fourth 'honourable and dishonourable vessels'; the fifth deals with 'those whose futures are foreknown and predestined'. $\mathrm{He}$ is aware that his answers to the questions put to him will not find favour with those who accepted fatalistic theory that the human race consists of 'two masses', the good and the evil and so deny the possibility that a large number of mankind can change themselves and the lives that they lead. But his approach to the question, though not acceptable to the learned and erudite, will offer ordinary people a clear, simple interpretation of relevant passages in the scriptures, sincerely held by himself. He goes on to urge his readers to respect the integrity of his treatise and ensure that the copy which they use does not deviate from the original text by changing the meaning or, indeed, any word or even letter. ${ }^{22}$ It is open to question whether, in fact, his exposition is as clear and simple as he claimed; it is certain that his original text

\footnotetext{
${ }^{21} 1980,113$, n. 22.

${ }^{22}$ I am not aware that attention has ever been drawn to the close verbal resemblance of this appeal to that made by Rufinus in the preface to... [the intended reference here is probably Rufinus' preface to his translation of Origen's De principiis I praef. Ruf. 4: Ne addat aliquid huic scripturae, ne auferat, ne inserat, ne immutet, sed conferat cum exemplaribus unde scripserit, et emendet ad litteram et distinguat... Compare De induratione 2: Hoc autem obtestor ... omnem qui voluerit hunc libellum habere, ut ad exemplaria ipsa, unde scripserit, diligenter emendet: non addat, non minuat, nec verbum pro verbo nec sensum pro sensu neque litteram pro littera].

Bryn R. Rees, “On the Hardening of Pharaoh's Heart,” in: Journal for Late Antique Religion and Culture 6 (2012) 1-54; ISSN: 1754-517X; Website: http://www.cardiff.ac.uk/clarc/jlarc
} 
must have been altered, miscopied and misunderstood over and over again in the course of transmission.

But he certainly adheres to his plan as stated, building his argument around passages of scripture referring to Pharaoh, Jacob and Esau and, in particular, to Paul's discussion of divine election in Romans 9:16-31 and elsewhere. He begins with the natural law, planted in human nature by God the Creator but later distorted under evil influence of the devil, so that it became necessary for God to supply his own divine law as a 'corrective of souls', subjecting man to the fire of faith in order to restore him to his pristine nature just as the human craftsman brings his material to the furnace in order to recast or restore it. It is grace that assists man to reach the fire of faith, and that fire consists in the application of the divine law to his free will, so that the response of that free will to it may enable him to emerge from the test with his strength restored and his sins purified. This process succeeds only with those who choose to submit to it; that is why not all are corrected and redeemed by it. The grace of the divine law is always available to all men and women but it is the grace of their human will which enables them to receive it in faith.

God has set out his law in the two testaments, the old and the new. The old testament has announced in advance the coming of Christ, the new reveals him to us and offers us the opportunity of profiting from his example and teaching in order that our lives may be changed by following the way in which they lead us. But the scriptures which are found in the old and new testaments are of two kinds: there is the kind which reveals the truth in simple language which is intelligible to everyone, and there is the kind which wraps its meaning in mystery. The first is intended as an aid to the understanding of the second; the more difficult passages can be explained in the light of those which are clearer, and they should not be allowed to prejudice our understanding [of] those which [are] easier to interpret. When the former and [the] latter appear to be contradictory, we need the help of an orthodox teacher who will not try to deceive his pupils by setting the teaching of the Old Testament against that of the New instead of showing them to be in substantial agreement with each other and thus to be complementary. God is incapable of contradicting himself; being good and just, he does not issue contradictory orders at different times. It was he who gave us the law, it was he who became man in order to restore us to our pristine state of righteousness which we lost through the influence of the devil. And by his law he persuades us to exercise our free choice in the right way so that by holy and pious works and pure hearts we may be able to bring him back to us.

When applied to specific texts and passages of scripture, this principle is shown to be correct. For example, Ex 20:5 - 'I the Lord your God am a jealous God, visiting the sins of the fathers upon the children to the third and fourth generation of those who hate me' - is said to be contradicted by Ez 18:4 - 'the soul that sins shall die' -

Bryn R. Rees, "On the Hardening of Pharaoh's Heart," in: Journal for Late Antique Religion and Culture 6 (2012) 1-54; ISSN: 1754-517X; Website: http://www.cardiff.ac.uk/clarc/jlarc 
and 20:4 - 'the son shall not bear the iniquity of the father nor the father that of the son but every man shall die for his own sin'. But there is no real contradiction: the two texts from Ezekiel are clear and straightforward and do not call for explanation, and they should therefore be employed as aids to the understanding of the one from Exodus. How could the God of mercy and forbearance, who utters the first two, also intend the third to be taken in a literal sense? Rather, it is a symbolic saying and should be interpreted as such: it refers to the inheritance which sons receive from the sins of their fathers and the effect of their evil influence.

Paul applies the same principle in dealing with the case of God's treatment of Jacob and Esau, when he illustrates the fact that 'God has no favourites' by explaining how God is said by Malachi to have loved Jacob but to have hated Esau not because of their works, since they were not yet born when he told their mother, Rebecca, that 'the elder will serve the younger' (Rom 9:11) but because of God's foresight, which permits him to know in advance those who will obey him and those who will scorn him and ignore his commands. The apostle goes on to compare the case of Esau with that of Pharaoh, posing questions which he then answers himself, not, as some wrongly suppose, making statements which express his own opinion. In the specific case of Pharaoh there is one truth that is fundamental, namely, that God 'desires all men to be saved and to come to the knowledge of the truth'. So, when Paul says that God 'pities those whom he wishes to pity and hardens those whom he wishes to harden', he is not making an affirmation but raising an objection such as an adversay might put to him at this point. In this instance, Pharaoh had hardened his own heart long before God began to say that He would harden it. Pharaoh had led a bad life; all God did was to hold back the plagues which could have put an end to his sins so that, in the end, both the deliverance of the children of Israel and the punishment justly visited on their oppressor might be more conspicuous. The true cause of Pharaoh's ostinacy is to be found in his exercise of his own free choice: he was given ample opportunity to 'repent and sin no more' but instead chose to continue to disobey God's commands.

God distances himself from Pharaoh because the devil has entered his heart, just as He does from the children of Israel when they provoke his anger in Isaiah's account of a day of judgment, telling him to keep to himself and not come near them. But, in doing this, he does show more than his power: he shows his compassion also, so that Pharaoh comes to admit that he and his people have been wicked in the face of God's justice. In this way God's punishment of the tyrant will not only bring great joy [to the] Israelites but give a salutary demonstration to the Egyptians of future generations of the overwhelming power of the God of Abraham, of Isaac and of Jacob. Job too is led to a true knowledge of God by chastisement, in his case for no obvious reason except for his need for greater enlightenment. Yes, Pharaoh and Job are 'treated to a dose of the same medicine by the same practitioner', and the latter

Bryn R. Rees, "On the Hardening of Pharaoh's Heart," in: Journal for Late Antique Religion and Culture 6 (2012) 1-54; ISSN: 1754-517X; Website: http://www.cardiff.ac.uk/clarc/jlarc 
receives the less sympathetic treatment because he is 'in all respects the stronger of the two'. But while Pharaoh is given just a hint that his bitter experience of God's scourges may stand him in good stead in the day of Judgment, Job's fortunes are restored and even doubled, and his latter days are more blessed than his beginning. The righteous man is tried in the furnace of tribulation only to emerge, like gold, corrected and reshaped but not broken.

As for vessels of honour and dishonour, how are we to interpret what Paul has to say on the subject? First, we must fix one fact in our minds and hold firmly on to it: God does not desire anyone's destruction, and he has fashioned everyone in his own image. Secondly, we can be certain that the scriptures, which reveal God's truth through the Holy Spirit, do not contradict each other; if they seem sometimes to do so, it is because we fail to use the texts that are clear to explain those which are not. When Paul says, 'God pities those whom he wishes to pity and hardens those whom he wishes to harden' and 'Therefore he gives this and that to whomsoever he wills', he means that, since God's will is wholly good and his justice undeniable, it is on account of their previous deeds that he has compassion on one man and not on another. Every man is an honourable or dishonourable vessel according to his own free choice between God and the devil; this is true, for example, of Saul, Jeroboam, Manasseh and David. When a man dismisses the Holy Spirit from his soul by misusing his right to make a free choice, God distances himself from him and will not return until he has repented and rejected the devil.

But how are we understand the apostle's statement that God has prepared the vessels of his mercy beforehand for glory, and made the vessels of his wrath for destruction? As we have often heard Paul say, 'God makes no distinction between individuals': He honours or dishonours them in accordance with the response which they make to his call, setting free the Israelites, who answered his call to serve him, but destroying Pharaoh and his Egyptians, who refused to do so and, in addition, persecuted those who did. If a man is disappointed with the treatment which he has received, he has the remedy in his own hands: he can amend his choice of his own free will and repent. God's call benefits only those who listen to it and answer it of their own fre choice; but God's prescience enables him to know in advance who will do so and who will not. It is only in that sense that we are 'predestined' to be God's elect. This was how the apostles became his chosen 'foreknown', 'predestined', 'called', 'justified', and 'magnified'.

There are, of course, people who try to introduce the dogma of fatalism by objecting that God, if he so wishes, will be able to sense all men or that honourable vessels are so treated by not dishonourable, and so such rewards are reserved for those who have been made to conform most closely to Christ. But there are many texts in the scriptures which attest to the contrary. And we know that Paul who described himself as the

Bryn R. Rees, "On the Hardening of Pharaoh's Heart," in: Journal for Late Antique Religion and Culture 6 (2012) 1-54; ISSN: 1754-517X; Website: http://www.cardiff.ac.uk/clarc/jlarc 
greatest of sinners, told Timothy at the same time that 'Christ Jesus came into the world to save sinners' but that it is for us to decide whether we are to be honourable or dishonourable vessels. It is we who have to choose whether or not to accept God's gifts offered to us through Christ. It is we who are called upon to run the race and win the prize, and that prize is open to all.

This is the voice of a true Pelagian, concerned above all in this treatise to expose the fundamental flaw in the doctrine of grace currently being preached by those who 'seek to advance pagan ideas of fatalism' by giving their blessing to a theory of predestination which is contrary to the received teaching of the Church on election. That is the purpose of his discussion of Pharaoh's heart, Jacob and Esau, and honourable and dishonourable vessels. At an early stage in the development of Pelagianism he put his finger on the aspect of Augustinianism which was later, c. 426, to disturb the monks of Hadrumetum when they read a letter in which the by then revered Bishop of Hippo expressed his views on predestination in their most extreme form. Shortly after in 427/8, it was also to stimulate his old friend and correspondent, Prosper Tiro of Aquitaine, and others to write to warn him of the unrest among the monks of Marseilles caused by his interpretation of election in some of his anti-Pelagian writings. ${ }^{23}$ Is there no good reason to believe that Augustine was regarded by the author of the De induratione as one of those who 'seek to advance pagan ideas of fatalism', possibly as their chief spokesman? Giovanni Martinetto has made out a strong case to support his view that Augustine was in fact the main target of our author. ${ }^{24}$

We shall return to Martinetto later. For the moment the more urgent question facing us is: Precisely who was the author of this treatise? It has been a matter for dispute ever since the ninth century when Archbishop Hincmar cited the work in his debate with Gottschalk - though, for obvious reasons, Pelagius was not suggested as a possible author at that time. ${ }^{25}$ And the question arose again as soon as the treatise was rediscovered by Morin at the very start of the twentieth-century revival of Pelagian studies but now in a different form: Is it by Pelagius or not? Morin, who was the first to suggest that Pelagius might be the author, and Plinval discussed the question in letters written to each other in 1932, when the former's illfated text passed to the latter. By then Morin had been convinced, and remained convinced, that the

\footnotetext{
${ }^{23}$ Aug. ep. 194 (CSEL 57, 176ff.); ep. 216.2.3 (CSEL 57, 397ff.); ep. 225 (CSEL 57, 454-68); ep. 226 (CSEL 57, 468-81); for a full account see B. R. Rees, Pelagius. A Reluctant Heretic (Woodbridge: Suffolk, 1988), 103ff.

${ }^{24}$ G. Martinetto, 'Les premieres réactions anti-augustiniennes de Pélage,' in: Revue des études augustiniennes, 17, 1971, 83-117.

${ }^{25}$ As we have already noticed, there was at least a difference of opinion as to whether or not Jerome was the author; see Morin 1909, 163, and PL 121, 1052B.
}

Bryn R. Rees, “On the Hardening of Pharaoh's Heart,” in: Journal for Late Antique Religion and Culture 6 (2012) 1-54; ISSN: 1754-517X; Website: http://www.cardiff.ac.uk/clarc/jlarc 
answer was in the negative, and Plinval at first agreed with him. Both felt that there were many stylistic reasons for not accepting it into the Pelagian canon which Plinval was busy establishing, and Morin went so far as to assert in 1934 that he could never bring himself to accept that the same man had written both this work and most of the letters and treatises already attributed to Pelagius by Plinval. The latter, for his part, in 1943, moved gradually in the opposite direction and, 'after long hesitation,' admitted the authenticity of the De induratione. ${ }^{26}$ By 1947, after rehearsing and weighing all the other possibilities - that the author was a contemporary, precursor or imitator of Pelagius - he appears to have satisfied himself that it belonged to his 'preclassical phase', when he had not yet discovered the expressions and speech patterns characteristic of his mature style. ${ }^{27}$ Nuvolone ends his brief discussion of the authorship with a reservation of his own, based on a detailed comparison of the vocabulary of the De induratione with that of the Letter to Demetrias: 'prudence,' he warns, 'is still essential. ${ }^{28}$ Martinetto, on the other hand, has no doubt that Pelagius is the author, and he may be right. But for the moment let us follow Plinval's advice, strange though it may seem to be, coming from him: let us be prudent.

It would be much easier to answer this question of authorship if we could be certain of the exact date when the treatise was written or even be able to agree on one that is approximate to it. In Morin's article of 1909 he expressed a preference for 'a date around the year 408 ' ${ }^{29}$ Plinval, however, after making his first examination of the text, favoured one between 424 and 430: 'The text,' he tells Morin, 'is not as old as you think it to be,' his main reason being the writer's use of language. In 1943, when he published his seminal book on Pelagius, he expressed no view at all on the subject, but, in 1947, in the introduction to his edition, he came to the conclusion, we have noted above, that 'the De induratione goes back to a period prior to Pelagius' classical phase,' meaning by that, presumably, the period before his Pauline commentary, which was written between 405/6 and 409; in the end he settles for 397-98. This date, he maintained, would also explain differences of details in the exegesis of the treatise and the Pauline commentary as well as the author's apparent ignorance of explanations given by Origen in his work On First Principles and by 'Ambrosiaster' in his Questions. ${ }^{30}$ TeSelle confirms and expands Plinval's comment on this ignorance of On First Principles and, in particular, Book III. He himself favours a date betweeen 404 and 405 - dismissing en passant Bonifatius Fischer's reversion to a date near

\footnotetext{
${ }^{26}$ G. De Plinval, Pélage. Sa vie, ses ecrits et sa reforme (Lausanne, 1943), 32, 43.

${ }^{27}$ Plinval 1947, 131ff.

${ }^{28}$ Nuvolone 1980, 117. As I shall explain later, I am not too happy about the value of such a comparison.

${ }^{29}$ Morin 1909, 188.

${ }^{30}$ Plinval 1947, 132ff.

Bryn R. Rees, “On the Hardening of Pharaoh's Heart," in: Journal for Late Antique Religion and Culture 6 (2012) 1-54; ISSN: 1754-517X; Website: http://www.cardiff.ac.uk/clarc/jlarc
} 
Plinval's early preference, that is 'after 428' and adding 'I am not aware of any place where he discusses his reasons for this assertion. ${ }^{31} \mathrm{He}$ is supported by Flavio Nuvolone, who must know this treatise better than anyone still alive today and, in addition, is not given to snap judgments. ${ }^{32}$ Others are sufficiently impressed by the arguments advanced by Giovanni Martinetto to give their vote to his date of 'around 399', which almost takes us back to Plinval's second and final choice. Martinetto argues that the De induratione, which he takes to be the work of Pelagius himself this is a corollary and an essential one to his own case, of course -, was written in direct response to the views expressed by Augustine in his Answers to Seven Questions for Simplicianus in 396-97 and that this can be proved by a careful comparison of key passages in the two works and the Pauline Commentary. ${ }^{33}$

The general problem of authorship and, alongside it, dating looms large in Pelagian scholarship. ${ }^{34}$ Indeed, it can be said to have first arisen in the decades following Pelagius' death, when his works were anathematized and began, for this reason and others, to be attributed to contemporaries, thereafter popping up in many unexpected places in manuscripts, editions and collections. For example, his Pauline Commentary was not attributed to him until the sixteenth century despite the fact that it had been referred to by Augustine not many years after it was written; it survived, however, in several MSS, including not a few which had been suitably emended and even bowdlerized and then ascribed to Jerome, who must have turned in his grave in response to such treachery. It was not until the twenties and thirties of this century that our first edition of the complete Pelagian text appeared after thirty years of strenuous and unremitting labour by Alexander Souter. ${ }^{35}$ If Pelagius' most important work could meet such a disappointing fate, what fate might the others which survive expect?

When Plinval became the first scholar to try to establish a Pelagian canon, he attributed nineteen writings to Pelagius himself, fragments apart. This was in 1934, and he added three more in 1943. In 1947 he removed seven from his list in the light of further reflexion on their suitability for inclusion and, it must be admitted, the criticism of others. ${ }^{36}$ Since then many more have been removed after application of less subjective criteria, and at present it is doubtful whether a disinterested reexamination would permit one to accept the authenticity of more than a handful of the works

${ }^{31}$ E. TeSelle, 'Rufinus the Syrian, Caelestius, Pelagius: Explorations in the Prehistory of the Pelagian Controversy,' in: Augustinian Studies 3, 1972, 84f. n. 86 and 83 n. 82.

${ }^{32}$ Nuvolone 1980, 115f. In his and Solignac's article in Dictionnaire de Spiritualite, vol. 12/2, 1986, col. 2919, he suggests a date between 405 and 409.

${ }^{33}$ Martinetto 1971, 106-117.

${ }^{34}$ See B.R. Rees, Pelagius. Life and Letters (London: Boydell and Brewer, 1991), 12ff. and in the introductions to the letters and treatises passim.

${ }^{35}$ Ibid. 13.

${ }^{36}$ Cf. Plinval 1943, 44f. and 1947, 8.

Bryn R. Rees, "On the Hardening of Pharaoh's Heart," in: Journal for Late Antique Religion and Culture 6 (2012) 1-54; ISSN: 1754-517X; Website: http://www.cardiff.ac.uk/clarc/jlarc 
ascribed to Pelagius himself at one time or another this century by scholars who have allowed their enthusiasm to outstrip their objectivity. Even today there are some who would be happy to accept most of the writings included in Plinval's corpus, no doubt on the ground that the pendulum has swung too far in reaction to Plinval's openhandedness. Be that as it may, the golden rule in deciding on the authenticity of any work of literature is to apply the strictest possible criteria, and Pelagian scholars have no claim for exemption from it, whatever their personal inclinations.

This treatise is a case in point. In some respects it presents an ever more delicate problem than many other Pelagian writings of uncertain authorship - and, in my view, they form the great majority of the extant works usually listed as 'Pelagian'. No one would be happier than I if I were able to promise my readers that by the time they reach the end of this book they will be in possession of a neat solution to the questions of authorship and dating of the De induratione. I shall do my best to give them some attractive pointers in one possible direction, and I may even be able to overcome my natural scepticism so far as to express a personal preference, especially if the solution offered were to lead us on to a better understanding of how, when and where the Pelagian heresy originated. If we could but be a little more certain of the date when the treatise was written, this alone would provide a most helpful guide through an area in which possibilities at present outnumber certainties and 'facts' are often no more than intelligent guesses.

Let us briefly consider the internal evidence only at this stage. On the negative side the vocabulary, syntax, phraseology and grammar undoubtedly fall well below those of the 'Evans letters', not to speak of the much more elegant 'Letter to Demetrias', with the writing of which Pelagius must have had some, probably considerable, assistance. ${ }^{37}$ Everywhere we look we see obvious signs of the writer's inexperience in composition and unfamiliarity with normal usage and practice. And yet we are bound to be conscious also of a lively, creative mind at work all the time, throwing caution to the winds in order to convince readers and plying them with ideas before the way for them has been prepared by reasoned argument, trying to hammer its points into them by constant repetition, straining the language so as to produce a flow of image, metaphor, symbol and allegory. As Plinval suggested, we are given the impression that the work is an improvisation, dictated at speed and with passion but never revised - if, that is, revision was ever intended. From the abundance of unusual forms of words including technical terms not normally expected in a theological context, the numerous examples of verbs, adverbs, prepositions and conjunctions used incorrectly and of tense, mood and voice misunderstood, of a plethora of anacolutha and instances of ellipse and syllepsis we would be entitled to deduce that we are dealing

${ }^{37}$ Rees 1991, 12, 33ff.

Bryn R. Rees, “On the Hardening of Pharaoh's Heart,” in: Journal for Late Antique Religion and Culture 6 (2012) 1-54; ISSN: 1754-517X; Website: http://www.cardiff.ac.uk/clarc/jlarc 
with someone in his infancy as a writer, not a native speaker, still in the process of fashioning a style of his own in a second language, one whose reading, possibly extensive but not in fields connected with theology, has not yet equipped him for literary composition. In this case it is not just a matter of lack of verbal and stylistic correspondence with other works of the kind that R. F. Evans was able to demonstrate so brilliantly in constructin his hypothesis of a close relationship between the four 'Evans letters', the Pauline Commentary and the Letter to Demetrias. ${ }^{38}$ Nor is there much point in comparing the vocabulary employed with that of the letter, which is a polished work and, almost certainly, the joint product of Pelagius' ideas and his amanuensis' writing skills. Stylistically speaking, the De induratione is anarchical, refusing to be categorized other than as experimental - 'a first shot', as Plinval says.

On the other side, however, it is undeniable that this treatise is Pelagian through and through - in subject-matter and in the spirit in which that subject-matter is presented: the central topics and features of Pelagian dialectic are all on display. Furthermore, there are distinct resemblances between statements and arguments found here and passages in the Pauline Commentary. Of course, it can always be objected that such correspondence can result from imitation, whether conscious or unconscious, and we have noted that Plinval discussed this possibility. But, whether or not the author of the treatise was Pelagius himself, he must surely have been associated with a circle of Christians who were accustomed to discuss such current theologoumena as grace and free will, predestination and election. And unless the invitation to write on them was not a fiction of his own creating, then he must also have been regarded as something of an authority on the subjects, one whose views were worth seeking. Was this the circle to which Pelagius and his friends belonged at Rome? That is generally supposed to be so. Could it have been in some other region of the Western Empire which was theologically articulate? In Provence or Aquitaine? In Spain or Sicily or even Britain? These are questions which must be left in the air for the time being and addressed only after we have read the text, considered its implications in detail and, in addition, compared it with Augustine's own expositions of the relevant parts of Paul's Epistles.

\footnotetext{
${ }^{38}$ What follows is mainly a brief resumé of Plinval's conclusions and the evidence on which they were based.

Bryn R. Rees, “On the Hardening of Pharaoh's Heart,” in: Journal for Late Antique Religion and Culture 6 (2012) 1-54; ISSN: 1754-517X; Website: http://www.cardiff.ac.uk/clarc/jlarc
} 


\section{TRANSLATION}

Preface

1. In their eager search for knowledge the most accomplished men are in the habit of demanding the views of very ordinary people of limited intelligence, coarse and rough in speech, on matters which they themselves are able to discuss with others with all the richness and brilliance of their own eloquence. It is as if a man of mature age were to bend over a baby's cradle and expect to hear it talking at a time when its age still denies it speech, and yet, after persistent coaxing, it were to utter a kind of speech, even though it is not quite what the listener wants to hear. In just the same way I see you, my lord and minister of Christ, confronting my total lack of expertise with the skills of a proficient examiner. And, as if it were not enough for me to have to face your demands, advancing upon me at the same time is a second, most shrewd examiner, one who scorns this world and leads the life of a monk under cover of his military cloak. It is to him that I have been instructed to give for transmission to you a homily on the subject of 'the hardening of Pharaoh's heart and of vessels of honour and dishonour'. ${ }^{39}$ It is not on my own wisdom that I rely, which is of no account, but on that of Him who, to confound the soothsayer Balaam, so confident of his own wisdom, opened the mouth of a dumb animal, as ass, assuredly, I approach my subject with God as my authority, on your instructions and with the support of your prayers. At the same time I ask that, if there should be anything here which is unworthy or not in accord with your understanding or in keeping with the choice flowers of your eloquence, since I shall be dealing with topics which perplex even the most accomplished, the wise reader will pardon me and lay the responsibility on you; it is your command that initiated this discussion, and your orders are powerful enough to wipe away every stain of incompetence from my name.

2. First, then, I give the reader notice that I have addressed myself to five topics in this work: the first is concerned with the words in the Decalogue, 'I shall exact payment for the sins of their fathers from the third and fourth generation of those who hate me (Ex 20:5); the second has to do with Pharaoh;

${ }^{39}$ [That is Romans 9:14-24.]

Bryn R. Rees, “On the Hardening of Pharaoh's Heart,” in: Journal for Late Antique Religion and Culture 6 (2012) 1-54; ISSN: 1754-517X; Website: http://www.cardiff.ac.uk/clarc/jlarc 
the third with Esau and Jacob; the fourth with honourable and dishonourable vessels; the fifth with those whose futures are foreknown and predestined. In this work I think that I shall please everyone who is prepared to change his life; but I do not doubt that I am going to cause displeasure to those who are seeking to promote pagan ideas of fatalism under a different guise, maintaining that human nature comprises two masses, the good and the bad, both made by God, and that some men have been made in such a way that they are totally unable to change themselves. They will gnaw at me with their teeth and seek every opportunity to tear me apart. But I can assure them that, with God's protection, I do not fear such attacks and that it is not to the erudite and learned but to plain and simple people like myself that I have tried to expound the meaning of divine scripture in simple terms. And I call to witness the coming of God's judgement and the majesty of the indivisible Trinity that everyone who wishes to possess this book should reexamine it carefully alongside the transcripts of the original from which he has copied it, adding and taking away nothing and without changing one word for another or one meaning for another or one letter for another letter.

\section{Divine Law and the Scriptures}

3. God, that excellent steward of human life, saw human nature [attention] diverted by the devil's influence from knowledge of Himself and the law which He had implanted in it scattered, as it were, and destroyed, a subject on which the prophet says: 'The unrighteous have scattered your Law (Ps 119:126).' Thereupon He applied the rule of Divine Law, as is well known in the same way as a craftsman in bronze or a metal founder would shape a mould of clay or wax to match the proportions of the statue which he has set himself to recast or restore, so that, by copying this likeness which represents its original in nature, it may be corrected to conform to the divine artificer's wishes. And this law He has made so secure by employing the strength of the truth and by striking fear into those who rebel against it that there can be no doubt that we have been given it as a corrective of our souls, in the words of the prophet David: 'Correct me in Your truth (Ps 25:5).' And just as He fashioned 
man in His own likeness He has divided it so as to be understood in two separate parts in the likeness of a man: as He made man from two materials, soul and flesh, so the body of the one law is shown to comprise the two tablets presented to Moses.

4. And just as He produced another human being from the man's side, one not being enough on its own to do what God the Artificer's will required, and just as these beings, though two in number, are of one flesh, so He brought two Testaments also into existence, one produced from the other, the New from the Old, that is, though they too are one by nature: what the Old conceived and announced in advance the New brought forth, namely, the redeemer and restorer of human nature, the Christ, whom the Old Testament promised, and who was hidden, as it were, in the Old Testament but is now revealed in the New. He, by His example and teaching, reshapes human nature and restores it to its pristine state with the hammer of His commandments and, at the same time, the incandescent fire of the Holy Spirit.

5. But if you seek to know why the whole of human nature is not corrected by that same Artificer through the law of the Old and the New testament provided by God the Artificer as a corrective of souls, we have to understand that, as the material which has been mentioned above and of which statues are moulded cannot be moulded at all unless it has been carried to the fire and placed in the furnace, so too human nature, once created, is tried and tested by freedom of choice; it will lie where it is for ever, broken and scattered, unless it extends its hand to the grace that draws it along with it as it walks with the aid of the will's feet, so that it may reach the fire of faith which, it believes, will recall it to its pristine beauty through Christ. At this point in the process you may believe but not discuss, seek humbly but not debate arrogantly.

6. That is because, if you offend the one who lies hidden in the letter of the law and reveals its mysteries to us, not only will those mysteries which you were boldly and rashly debating be concealed from you but even those which you already know will be shut away and consigned to oblivion, as the scripture tells us in the words of Solomon: 'God sets Himself against the proud but gives grace to the humble (Ps 3:34).' And what else are we to understand by 'grace' but the wonderful mysteries which are hidden in the Divine Law but revealed to us? It is for them that the prophet David cries when he says: 'Open my eyes, 
Lord, and I shall see the wondrous things that came out of Your Law (Ps 119:18).' This Law we know to have been laid down by God as a model or corrective, as we have said above; in it all believers are recognized, just as Christ was in the pattern of God the Father according to the witness of the apostle when he speaks of himself in another passage: 'When I was under the Law of God, I became as one without the Law, so that I might win over those who were without the Law (1 Cor 9:21).' This law God divided into separate parts and surrounded with mysteries in such a way that it is not the one who listens to it with a yawn that is corrected but everyone who seeks it believing it with all his heart, so that there might be a distinction, as the prophet tells us, between the one who seeks God and the one who does not, between the one who serves God and the one who does not (cf. Mal 3:18). He has so veiled it in mystery that the value of understanding it may be obvious to godly seekers but that it may remain for ever hidden from the proud.

7. This law, then, which renews man, shattered as he is by the great age and long duration of his sin and stained by the blackness of his crimes, we know to have been given to us through Moses as if in the likeness of a man. For a man, though he is only one in body, is clearly composed of several members joined together, some of them visible, others invisible, that is to say, located within his internal parts. So the law too, though allotted only one name, is demonstrably like a man in possessing many members, as has been already said, and these are both visible and invisible, both transparent and concealed by great and dark mysteries. God has placed them in the body of the Divine law for man's benefit and with good cause and reason, just as we can see that individual members have been placed by God the Artificer in the human body each in its proper place, some in the open, others in concealment. It is also clear that some members are superior to others and that individual parts manifestly perform the functions required of each of them. And, though all the parts in the body are equally necessary, yet the head, eyes, ears, face and whatever else is a part of the head are, as everyone knows, superior to the rest and give the body as a whole its elegance. To ascertain whether some part of the body is to be counted as good or not, as precious or as worthless, it is subjected to the approval of the eyes either directly or in its secret place; so too the Law is acknowledged to have many parts, some comparable to the eyes and the ears, others located 
within like vitals and comparable to the less accessible parts of the body. As we have said, therefore, you must realize that the Divine law was given to us through Moses in the likeness of man in the same way as man is said to have been made in the likeness of God.

8. For, as man, fashioned by God's hand out of two materials, that is, soul and body, received the name 'man', so too the law, fashioned on two tablets also by God's hand, received the name 'law'. This law was somehow to restore and regenerate man and restore him to his original state by its admonitions, so that whatever had been forgotten by man in his sinning and ignorance and on the prompting of the Devil, this Moses might now recall to his memory and depict before his eyes; the apostle confirms this when he says: 'The law is our tutor (Gal 3:24),' and: 'I would not have known what it is to be covetous, did not the law say, 'You shall not covet (Rom 7:7).'

9. If, then, a man gives careful consideration to the fact that the law is divided into individual parts and that some of them are easier to understand than others, he will not be able to find it a stumbling-block when he comes across passages which are more difficult or obscure than others so far as understanding the divine mysteries is concerned, so long as he has grasped that the Divine law comprises many parts. Some are very clear and comparable to the eyes and ears but others are more recondite, performing the functions of the vitals, as it were, and wrapped in great obscurities which the hearer is unlikely to understand without the help of an orthodox interpreter. He will also find that it will be necessary for the children of the Church to realize that, as any matter in the body is brought before the eyes for investigation when necessary either directly or from its secret place of hiding, so too these spiritual matters which are too remote and profound for our mental powers to grasp and have been proclaimed by the Holy Spirit to test the strong - all the more obscure texts, that is, which perform the same function as the internal organs - must also be set alongside the meaning of those texts which are like eyes, being transparent and not in need of an interpreter. In this way the more difficult passages can be explained in the light of those which are more clear-cut, and the more obscure are not permitted to distort the meaning of those which are obvious. For example, there is the passage in the Decalogue in which the Law of Moses originates - or, rather, the Divine Law is recreated in writing after having been 
given to us by nature long ago - and where it is said: 'I am the Lord your God, who brought you out of the land of Egypt; you shall have no gods but me. You shall not make for yourself any likeness of the things which are in the sky and on the earth or in the waters, and you shall not honour them nor worship them. You shall not kill a man; you shall not commit adultery; you shall not covet anything that is your neighbour's. Honour your father and mother (Ex 20:25.12-14.17);' and: 'You shall love the Lord your God with all your heart and with all your mind and all your strength (Dt 6:5);' or there is the statement on which the apostle says that all the Law and prophets depend: 'You shall love your neighbour, He says, as yourself (Lev 19:8; cf. Rom 13:9 etc.),' and: 'Whatsoever you do not wish to be done to you do not to another (Tob 4:15), and many similar passages. Have they any need of an interpreter or a symbolical explanation? Surely they are rather to be compared to the eyes and ears.

10. Passages, however, which are obscure and beyond our mental powers or which seem to contradict the unambiguous ones mentioned above, for example, the one in which God says: 'I am the Lord your God, a jealous God, exacting payment for the sins of the fathers from their children to the third and fourth generation of those who hate me (Ex 20:5)' - and are said by us to correspond to the remoter parts of the body, these have to be referred to others which have a meaning which requires no interpreter; in that way statements quite appropriate to their own con-texts will not be damaging to our faith, as has already been said, or affect the right use of our reason. For how can they possibly be in accord with God's forbearance or be taken in the literal sense if that means that the true God, who is compassionate even to excess, who did not think it beneath Him to humble Himself for sinners and human weaknesses, who daily forgives our own sins, could heap upon others sins for which they were not personally responsible - especially when He, the same God who spoke here through Moses, Himself says elsewhere through the prophet Ezekiel: 'The soul that sins shall itself die (Ezek 18:4.20)'? He who had previously said that He exacts payment for the sins of the fathers from their children now says: 'The son shall not bear the iniquity of the father nor the father that of the son but every man shall die for his own sin; for both the father's soul and the son's belong to me (ibid.).' Surely passages like these call for no explanation. But 
those which seem to contradict them in some passages do need an interpreter because of the inadequacy of the less intelligent, in order that statements which are obscure may agree with those which are self-evident, thus perhaps preventing us from believing that God has contradicted Himself in the manner of a frail human being. But it is when a man is influenced by someone in authority or hoodwinked by his own ignorance and personal weakness or tainted with the black mask of falsehood that we must believe him to be contradicting himself.

11. But as for God, all-powerful, true, free of any stain of weakness, endowed with foreknowledge, a just judge full of all manner of goodness, bowing to no one's authority - how could He issue contradictory orders? $\mathrm{He}$ who both gave us the Law and did not disdain to become man, in order that through that same Law and by means of persuasion He might restore man to his original state of righteousness, the state from which he had fallen into this vale of tears under the devil's persuasion, bending the human heart to his will with the poison of his own wickedness. And it is this Law which was intended to persuade man by virtue of his possession of free choice to draw God, his Creator, into his soul by holy and pious works and through the cleanliness of his heart, just as he had previously drawn the devil into his wretched heart to reside there by his vile and bloody deeds. Therefore, that we may believe that both these passages come from a good and just God and are divine and that it was the same God who spoke in both instances, saying through Moses, 'I shall exact payment for the fathers' sins from their children', and then through Ezekiel, 'the soul that sins itself shall die', the rule of our faith must be applied in accordance with the principle stated above, and passages which we find less easy to understand explained in the light of the meaning which is plain to everyone and is, as we have said, to be compared to the eyes.

12. Thus, when God said that He exacts payment for the fathers' sins from their children, it was not because He was unjust but so that men might be frightened into desisting from sin if only to avoid leaving a baleful inheritance to their sons by scurrying around hither and thither on their behalf, inflamed by the fire of their greed but without fear of falling into hell themselves and with the sole purpose of leaving them rich in this world. For the symbolical interpretation of the text is that sons receive what they do receive in return for 
their fathers' sins by being led astray along the path of vice through the evil influence of bad company and upbringing and, for their persistence in sin, receiving in the end a punishment long postponed by God's forbearance. The sins of the fathers are paid for by their sons when the wicked man is scourged for the sins which he has received from his father, the devil, as if by law of inheritance and with the consent of the one who begot him in evil; those to whom the saviour says: 'You come from your father, the devil, and it is the works of your father that you wish to do (John 8:44), were begotten in this way. It was especially on their account, I think, that this allegorical saying was uttered, in order that even the wicked man, scourged as he is in this world for his father's, that is the devil's, sins, which the latter had heaped upon him by the latter's persuasion, may return after his chastisement to his true Father, God, who fashioned him in His own likeness. To show that it was an allegorical statement that the sins of the father were to be heaped upon his children and that in him this was extended to apply to the stiff-necked people of Israel in keeping with the meaning given by ordinary folk to the proverb, to which the Lord bears witness on oath through the prophet Ezekiel, saying: 'As I live, if this proverb is used again in Israel, that is "The fathers have eaten sour grapes and the children's teeth are set on edge" (Ezek 18:3.2),' and: 'But everyone who eats sour grapes, his teeth are set on edge (Jer 31:29).' This saying, then, which in its original context had been uttered in order to lessen the number of sins committed, the common people had turned into a proverbial expression when they saw the sons of evil men prospering and this not turning out according to the literal sense they railed at God's way as if it were not straight, and it is for this reason that they were taken to task by the Lord in the words of the prophet: 'It is your ways that are crooked; yet you accuse mine of being less straight (Ezek 18:29).'

\section{Esau and Jacob}

13. How like this is the method employed by some of our contemporaries who are at fault in their treatment of many passages of scripture because they are always looking for a literal sense! This is especially true when they refer to 
the hardening of Pharaoh's heart or when they deal with statements made by the blessed Paul in the passage where, like a great orator, he poses to himself and then answers questions on the subject of Jacob and Esau and, like a teacher who knows in advance the arguments which his opponents are likely to put forward, himself puts them to the sons of the Church and interprets them for pious enquirers. Of the aforementioned Jacob and Esau he says: 'Though they were not yet born and had done nothing good or bad, in order that God's purpose might be fulfilled with regard to election, not because of works but because of the one who calls she, that is, Rebecca, was told that 'The elder shall serve the younger' (Rom 9:11). And so as to make it clear that it was not his own point of view but the literal sense of the prophet that he was stating in this passage, the apostle did not hesitate to appeal to Malachi, who was one of the twelve prophets writing in versicles: "As it is written, "Jacob I loved but Esau I hated" (Mal 1:2.3).' In explaining this literal sense to pious enquirers he made God's prescience quite clear, how God's prescience loves those who obey Him because He foreknows what they will do, whereas He tolerates those who scorn Him because He foreknows them also.

14. But to ensure that, while he was proclaiming God's prescience to his hearers, those who misunderstood him would not form the opinion that God makes a distinction between one individual and another, he added: 'What then shall we say? Is there injustice on God's part? Certainly not!' (Rom 9:14). That is to say, It is not a mark of God's ill will if the younger rules the elder but because he is the one who places his hope in God, who humbly and only reluctantly submits to his mother Rebecca's persuasion when she urges him to hasten to the field and bring back the wherewithal to prepare a meal for his father. Thus the prophecy made to Rebecca would be fulfilled in the person not of the one who trusted in his sword and bow but of the one who crossed Jordan in flight with only his staff to support him (cf. Gen 32:10), the one who says, 'The God of my fathers who has nourished me from the time of my youth will save me' (cf. Gen 71:17ff.), not the one who says, 'The days of my father's death are approaching, and I will kill my brother Jacob' (Gen 27:41). Such as Jacob are those whom God's prescience has chosen to occupy the citadel of His kingdom, that is, those whose trust is not in their own strength but in God, those who emerge as victors not by relying on visible weapons but through the 
invisible weapons of heaven; such are those whom He has chosen to bear the likeness of Christ. They are the ones to whom this mercy is given, who are suddenly lifted up to glory out of the depths of despair, who do not sell the goods of heaven to satisfy the gluttony of their belly and its voracious demand for instantaneous nourishment; it is in such as these that He deigns to live, the ones who despise the food of this life and, by so doing, purchase the privileges of Heaven.

15. In order to teach us that the words of Moses and those of the holy prophets came from one and the same Holy Spirit, who always shows mercy when dealing with the humble but the severity of his justice when dealing with the proud, he later demonstrated that no change of injustice can fall upon God, using the words of Malachi on the subject of the hatred directed at Esau and the love bestowed on the patriarch Jacob. He also quotes a similar message addressed to Moses on the same topic, which was mentioned above. 'Is there injustice on God's part?' he says, adding: 'For He says to Moses, "I will have mercy on those on whom I have mercy, and I will show pity to those [for] whom I will have pity" (Rom 9:14.15). Surely He is making it clear that Jacob suffered cruel persecution at the hands of Esau, as did his progeny at the hands of Pharaoh in Egypt. Therefore, God shows pity when He sets free the one who prays to Him; He dispenses compassion when He raises the poor man up from the ground and sets him on a throne of glory. Having developed the preceding case, the apostle then makes it clear also that all that happened in the case of Jacob and Esau did so because Esau 'wished' and 'ran' in the chase so that the wild animals taken might provide food for his father, and so the latter, refreshed, would honour him with the gift of his blessing. This we know most certainly to be put into effect both for the good and for the bad, and he says of them: It does not depend on the one who wishes or the one who runs (ibid. 16). But since it was a perjurer who now 'ran' and 'wished' to seize the rights of precedence which he had lost of his own choice and because of the oath which he had taken in return for just one meal of food, his 'running' was in vain, and the runner's 'wish' was evil; for it would have been paradoxical for him to gain from the words of his father's blessing that very right of precedence which he had voluntarily surrendered to another for the prize of one miserable meal of lentils and to satisfy the pressing demands of his gluttony.

Bryn R. Rees, "On the Hardening of Pharaoh's Heart," in: Journal for Late Antique Religion and Culture 6 (2012) 1-54; ISSN: 1754-517X; Website: http://www.cardiff.ac.uk/clarc/jlarc 
16. And so Paul, the teacher of the Gentiles, presents us with a case involving two kinds of people, the righteous and the wicked, in Jacob and Esau, in order to teach us that it is God, not man, who confers on us the precedence which is a mark of honour, and that the one who gains possession of it is the one whom God, not man, has chosen. Esau had been chosen by his father to do the work of hunting; his father 'wished' him to have the precedence to which he so aspired, and the son 'ran' for the hunt with all the eagerness and speed which he could summon in the hope of regaining the precedence which he had lost for so long. But Jacob holds his peace; he does not 'run', he does not wear himself out by hunting over the hills and plains so as to acquire a right of precedence which he was absolutely sure that he had already bought for the price of a handful of lentils - Esau had lost it not by force but of his own free will! Jacob is reluctant to rob his brother of a privilege which he already possessed; but his mother puts pressure on him to fetch the werewithal to provide his father with a meal, duly refreshed by which he would bestow his blessing on him: And Jacob announced, 'I fear that my father may touch me and then bestow a curse on me instead of a blessing' (Gen 27:12). But for the acquisition of the right of precedence it is not simply a matter of Isaac the father's 'wishing' or of Esau the sons's 'running' for the sake of his belly and gluttony but, rather, of the goodness of God when He 'has mercy'. And this was consummated for the first time in Jacob, in order that from that example we may learn to place our hopes of preferment on God, not man. For, in this passage, the apostle is speaking of no other 'running' but 'running' to acquire precedence, when he says: 'It does not depend on the one who is "wishing" or the one who is "running" but on God, who has mercy' (Rom 9:16); the 'running' of the one and the 'wishing' of the other were to no purpose.

III. Pharaoh, a comparable case

17. And so that we might not perhaps consider the fault found in Esau to be unique, the apostle compares with him Pharaoh, King of Egypt, and illustrates how the devil is continually stirring up trouble for the saints through his accomplices. The scripture, he adds, says to Pharaoh, 'I have raised you up with 
the very purpose of showing my power in you and that my name be proclaimed over all the earth' (ibid. 17). It is evident that the blessed apostle is here confirming the fact that one and the same mercy is at work in the liberation of the people of Israel as in the matter of Jacob the patriarch's right of precedence. For God Himself said to Jacob when he fled: 'Fear not, for I shall be with you' (Ex 3:12), just as He later said to Moses when he was afraid: 'I shall be with you and shall make you a god to Pharaoh, and your brother Aaron will be your prophet' (Ex 7:1). And in order that he would not be reluctant to delay the liberation of the sorrowing people, he foretells that He will harden Pharaoh's so that for a while he will not agree to release the men being kept in prison but will do so only after having been scourged with many prodigies. These prodigies would turn out to be beneficial, because in Pharaoh's destruction the power of the true God, which still lay hidden from all the nations, would be revealed.

18. The majority, therefore, unable to comprehend the true meaning of divine scripture and seeking it without really believing it, are in error when they try to explain Paul's words, especially in this passage in which he deals with Pharaoh and vessels of honour and dishonour and, in the manner of a professional lawyer, raises questions and introduces different persons to put them to him. Some do not understand what he is doing and suppose that he has given, as we say, his own definitive judgement with the words: 'So, then, God pities the one whom he wishes to pity and hardens the one whom he wishes to harden' (Rom 9:18); in fact, Paul is merely replying to and refuting the irreverence of another when he says: "Then you say to me, "Why does He still find fault?" For who can resist his will?' (ibid. 19). It is demonstrably from his own lips, as has been said before, that Paul introduces this question and is also seen to be discussing the mysteries of the Law with him as one who wants to put questions not for the sake of his own soul's progress but in order to start an argument and show off his verbal skills in the course of it. Here we have a man who, before he has come to believe in God and to know Him through learning His nature, wishes to get to know by discussing His works one whom he is unwilling to get to know by believing in Him; he wishes to understand His works and His will and to become his judge before recognizing Him as his own Judge and Creator. This, then, is the man whom the apostle reduces to silence by saying: 'Who are you, a mere man, to answer God back? Does what is moulded 
say to its moulder, "Why did you make me like this?" Does the potter not have the right to make out of the same lump of clay one vessel for honour and another for dishonour?' (ibid. 20, 21).

19. What if we admit that the apostle explained the matter in the way that those whose belief is distorted think that he did, and if we accept that the blessed Paul - the very Paul who declares that 'God wishes and desires all men to be saved and to come to the knowledge of the truth' (1 Tim 2:4) - state his opinion of our most merciful God to be that He has pity on the man on whom He wishes to have pity and [hardens] the one whom He wishes to harden? In that case, he will manifestly be making out that a good God is not good but he will also be seen to be attacking himself, since he affirms elsewhere that the principle that 'God makes no distinction between individuals' is approved without reservation in many passages of scripture. For if it were to be believed, as heretics suppose, that Paul was quite bluntly insisting that 'He pities the man whom He wishes to ptiy and hardens the one whom He wishes to harden' - and may God forbid that this should be the true catholic meaning of this sentence! and not rather that his statement was intended to be a rebuke and a refutation of an irreverent fellow, then the 'good runners' have had their final sentence pronounced on them! It is of no avail that human nature received the commandment: 'You shall love your Lord and God with all your heart and with all your soul and with all your strength' (Dt 6:5) and through the prophet Isaiah: 'If you are willing and obedient, the Lord has said you shall eat the good things of the land; if not, the sword shall devour you' (Isa 1:19,20); and our Redeemer, Christ Himself, confirms this with a solemn oath when He says: 'Truly I say to you that whoever asks receives, whoever seeks finds, and whoever knocks, to him it shall be opened' (Lk 11:10; Mt 7:8).

20. Or, again, how can a man love his Lord and God with all his heart, if God Himself then hardens the heart with which we have been commanded to love Him? If this is all that we think, if He pities some by softening the heart within them towards belief but hardens others by not softening them, then $\mathrm{He}$ does distinguish between one individual and another. In that case, it is all to no purpose that we have been given the Law to hold a man back from sin and lead him to the Kingdom of Heaven by means of persuasion; it is to no purpose too that Christ, our Redeemer, Himself suffered in order to leave us the example of 
His suffering, as the apostle testifies (1 Peter 2:21). Surely it is not possible for the apostle to contradict himself. He is trying to establish by every means at his disposal that Christ suffered for us in order that His example might persuade us to approach with gladness to have our sins melted away in the fire of suffering and tribulation. By this means, just as we have followed in the footsteps of the devil in sin and along the delightful but ruinous path of pleasure, so, by restraining ourselves from indulging in forbidden things and instead loving humility and gentleness, we may follow in the steps of Christ. It was He who said: 'Learn from me, for I am gentle and lowly in heart' (Mt 11:29); and who also lamented over Jerusalem with the words: 'How often would I have gathered your children together as a hen gathers her brood under her wings, and you refused' (Mt 23:37). Had He not known that He had implanted freedom and reason in human nature, which is itself a proof that the Creator is a stranger to the idea of predestined destruction, no man would ever be praised for willing the good or blamed for rejecting it. And so, once this dark, ungodly suspicion has been removed [from] wicked hearts, we know that neither God, the author of the Law, nor His apostles have contradicted themselves; justice does not permit us to believe that even any human being of a serious and sound mind does this, since God Himself reveals all things to us.

21. Let this rule of faith which comes from the Fathers and the apostles be firmly imprinted on our hearts: God makes no distinction between individuals whether in acquitting or condemning them but everyone must be examined before Christ's tribunal according to the quality of his deeds. And all statements which appear to be obscure or inconsistent with the unequivocal texts cited above, which resemble eyes and ears, must be brought out, as it were, from the depths of their cave into the light of faith. The clarity of that faith will then make it evident that the Divine Law has been inspired by the Holy Spirit and, though it may be expressed in different words, gives one meaning and one only.

\section{The hardening of Pharaoh's heart}

22. Once all this has been firmly rooted in our minds it will be an easy matter to understand how and by whom and for what reason Pharaoh's heart 
was hardened and why one vessel is made a vessel of honour and another of dishonour, despite the fact that both have been taken from the same lump of clay, especially when we are told that both were made by Him who, according to the apostle, makes no distinction between individuals. The answer to these questions will become abundantly clear if we examine the sort of life lived by those of whom we are speaking before this happened to them. If Pharaoh is proved to have lived a good life up to the time when God said to Moses, 'I will harden Pharaoh's heart' (Ex 4:21), there will obviously be a suspicion that, as some crazy people think, God hardened Pharaoh's heart solely in order to have someone to kill off in the Red Sea! For this God, who, on Christ's testimony, is the only one who is good by nature, that is, of unchangeable goodness, since $\mathrm{He}$ says: 'None is good save God alone (Mk 10:18),' and by the witness of the apostles and all the prophets, 'makes no distinction between individuals' - this God, I say, will be judged to have done to the whole mass of humanity whatever He has done to a single individual. But though His power is so great that $\mathrm{He}$ is able to do whatever He likes, and no one can say to Him, 'Why have you made me like this?' (Rom 9:20), yet He has in Himself reason and justice and goodness, and these so affect His power as to prevent anything being done which is inconsistent with goodness or open to criticism by the devil. So, if only to satisfy those who, being unwilling to correct their own way of life, ascribe the hardening of the heart to God, let us now try to discover what sort of a man Pharaoh was at the time when God first said, 'I will harden Pharaoh's heart' just in case he was good at one time but was later made bad as a result of this utterance.

23. What are we to make of the evidence given by our reading of Exodus to the effect that his, Pharaoh's, life had been in all respects like that of the devil himself far back in the past for years beyond number before God spoke to Moses about him and that he had committed the most heinous of crimes? It was in return for these that his heart was allowed to harden for many years afterwards right up to the point when he reluctantly let go the people whom, like a lion that has grasped its prey in its claws, he was engaged in cruelly killing off by wearing them out in the clay and bricks and by submerging their innocent, newborn babies in water. And it was in response to their grief and lamentation that, moved by pity, God came down to set them free; the scripture 
tells us that, after Joseph's death, Pharaoh said to his people, 'The people of Israel are many; come, let us be shrewd and destroy them in case war befalls us and they join our enemies and fight against us and escape from our land' (Ex 1:9-10). All that happened thereafter is narrated in the history of Exodus.

24. If, then, there is any doubt as to how or why or by whom Pharaoh's heart was hardened, let us try to find out on whose instructions Pharaoh came to devise his cruel plan to kill off the people in this way; our enquiry about who hardened Pharaoh's heart for this killing, so that eventually he died in the way that he did, will then be complete. There are three suspects: God, his own free choice and, if in fact that choice was in accord with the devil's, the devil. If, therefore, Pharaoh's heart was hardened by God - and God forbid that this should be the true, catholic sense of the text! - then He who wishes no man to perish ought not to have said, 'I will harden', but 'I have hardened' Pharaoh's heart. In which case He would be seen to have been speaking of a hardening in the past and not in the future, since the crime which he was perpetrating on God's people was already being committed long before God said that $\mathrm{He}$ intended to harden his heart. But if Pharaoh hit on such an idea on his own, then, quite obviously, it was he himself who hardened his own heart. And if, again, it was done by the devil, Pharaoh could put it down to his own folly none the less, since it was his own choice to extend his hand to the devil and permit to be installed as the inhabitant of his heart the very one who hardens every heart, once he has entered it, so that it conforms to his will, and in this case it was the heart of Pharaoh.

25. And so, if anyone has the audacity to babble wicked nonsense to the effect that God predestined Pharaoh to die by such a death as he did and that it was for this reason that $\mathrm{He}$ said that $\mathrm{He}$ would harden his heart, he should first consider the import of the statement which He made: God does not say, 'I have hardened', but 'I will harden'. It was not His intention that Pharaoh should make a brutal assault on the people and do evil things to them but that, by a postponement the blows by which he deserved to be killed in return for his earlier deeds, he would be led on this one occasion to the very death by which he had killed the children, that is, into water. For God explained the reason why Pharaoh was being hardened when He said: I will harden his heart, and he will let you go only after great signs (cf. Ex 7:3). This means that Pharaoh's own 
wickedness would bring him to that very death by which he had killed the innocents, and so, after failing to comprehend just whose anger he was belittling when scourged by other calamities, he would meet his final punishment in the waters. These very waters, the ones which he had earlier stained with innocent blood, would then exact vengeance from the impious Pharaoh before the eyes of the children of Israel. For God's justice demanded that the Egyptians be slain by the same punishment, that is, water, which they had used to slaughter the Hebrews' children. This suggestion of the reason for Pharaoh's death is in accord with the Saviour's words when he says of the Jews: If I had not come and spoken with them, they would have no sin; but now they have no excuse for their $\sin$ (John 15:22).

26. There are some who persuade themselves that, if God had not sat the people free from Pharaoh's hands in response to their cries of protest - the occasion of the saying, 'I will harden Pharaoh's heart' -, He would not have become, according to their crazy way of thinking, one who distinguishes between individuals. But you must realize that the words, 'I will harden Pharaoh's heart', and 'he will let you go only after great signs' were uttered in order that this impious man, though chastised by the signs, which acted as cauteries that are the proven instruments of the healing of goodness, might suppose that God was unable to set His people free. In the meantime, Moses, his resolve greatly strengthened despite these delays and forewarned of the outcome, would be able to strengthen the resolve of the children of Israel too, querulous though they were and worn out by the severity of their enslavement. Indeed, these words, 'I will harden Pharaoh's heart', can be seen to come very close to those in the gospel where it is said of Judas: 'When the Saviour had offered him the morsel of food, Satan entered into him to betray Him' (John 13:26-27). But if we conclude that God wished Pharaoh to die from the fact that $\mathrm{He}$ said that $\mathrm{He}$ would harden his heart, we should also believe that Jesus became the cause of His betrayer's undoing by offering him the morsel of food, although, even at that late hour, He still invited him with His customary kindness to repent, saying: 'Judas, do you betray the Son of Man with a kiss?' (Lk 22:48). If Jesus was unwilling to accept a penitent, then Pharaoh would never be worthy to hear the voice of the Lord saying through Moses: The Lord of the Hebrews says, 'Let my people go, that they may serve me' (Ex 7:16); nor 
would Jesus have said to Judas: 'Woe to that man by whom the Son of Man will be betrayed (Mt 26:24).'

27. Pause then and open your heart to listen and consider the apostle's meaning: he does not claim that the scripture said, 'It was for this purpose that I hardened you', but, 'It was for this purpose that I raised you up, that I might show my power in you' (Rom 9:17). Thus Pharaoh is like a lion or a serpent lying on a rock, poised to kill the Hebrew people. One does not describe someone as being 'raised up' unless he is lying down, as the prophet Ezekiel shows when he says that Pharaoh is lying down in the middle of a river like a serpent with the words: 'Say to Pharaoh, "Great serpent, lying in the midst of the stream and saying, »The stream is mine, and I made it myself «" (Ezek 29:3). So, according to this passage Pharaoh was surely lying in wait there like a serpent, intent on doing harm to the Hebrews, and when the Lord wanted to wrest from him the prey which he held in his grasp, he had to be 'raised up' to hear the Lord's voice. Like a great hunter God did not wish to kill the beast in his lair, that is, in hiding, but instead, by postponing his death, He enticed him to come out into the open plain, so that the whole world might marvel at the killer's power. We can, then, take it as certain that the Lord in His goodness hardens Pharaoh's heart by removing His plagues and not inflicting them on him. For, whenever the plagues ceased to trouble him, scripture reports on each occasion: Pharaoh hardened his heart and refused to let the people go, as the Lord had said to Moses (Ex 9:35). In like manner Isaiah the prophet also complains about this hardening of heart in the name of his mourning people: 'Why, Lord,' he says, 'have you made us stray from your way and hardened our heart, so that we do not fear you?' (Isa 63:17). And in the passage following he explains in a sorrowful tone the reason why their heart had been hardened: 'We have become,' he says, 'as we were in the beginning, when you did not rule over us and when your name was not invoked over us' (Isa 63:19).

28. Do you see that it is because of their evil deeds in the past and the stench of their wickedness that God, who inhabits their hearts, distances Himself from them, He who had previously said, 'I shall reside in them' (Ez 43:9)? And when God distances Himself in this way, His control over us and His care for us cease, and when His care ceases and leaves us, the devil approaches our heart and models our mind, which he finds empty of the fear of God, to suit the cruel 
demands of his own will. Once this has happened and the devil becomes the inhabitant of our heart, he entwines himself inevitably about our soul with his foul and evil-smelling presence. He is the evil spirit, the spirit which inserts itself within another spirit and, like the substance, he binds and joins to his own evil the heart which he now inhabits, as the prophet tells us, when he says: 'Their heart has been curdled like milk' (Ps 119:70). And when that happens, we become of necessity as we were in the beginning, that is, at the time when we did not invoke God and there was no law in our hearts and we were no different from wild beasts. The withdrawal of God, the proximity of the devil that surely is what hardening of the heart means. As long as a king, however irreverent, believes in the God of heaven, he is not surrendered to the possession of the devil so completely as not to feel even the blows rained upon him; he is still entitled to receive a warning through God's messengers, and his heart is still said to be 'in the hand of God' (Prov 21:1).

29. But when a man has given his right hand to the devil, saying: 'I do not know God (Ex 5:2), 'the devil receives him into his possession as his own property and, by crushing him under the burden of his earthy and filthy deeds, no longer permits him even to think of his Creator. This is what happened to the wretched Pharaoh, as it happens to all like him. Having inserted himself in his heart and settled himself down in control of his foul and bloody actions, the devil changed the good in his nature like gold into mud, and this the Lord cast from his hand into the fire in horror like a lump of mud; in other words, $\mathrm{He}$ allowed him to leave His own protection and to be turned over to the power of the devil. It is he who is meant by the 'fire' which, the Saviour declared, 'fell like lightning from heaven' (cf. Lk 10:18), the furnace, that is, which makes the golden hearts of the righteous gleam and glitter but hardens the muddy hearts of the ungodly in accordance with His will, as it is written: 'The king's heart is in the hand of God, and He turns it in whatever direction He wishes' (Prov 21:1).

30. But because God's will is wholly good, He turns the king's heart in the direction prescribed by reason and justice, not power alone. So, when someone becomes the kind of person who is liable to be abandoned by God, he begins to be at one in spirit with the devil, who is described as 'the furnace', and inevitably, on drawing close to him, is hardened like clay by the fire. Undoubtedly the Lord foresaw that Pharaoh's heart would deviate towards evil 
and, once approached by the devil, would be fired with eagerness to destroy the innocent. He promises to harden his heart in order that, as we have already said, he would become slower to let go those whom he so cruelly held in his clutches. And so, after being subjected for a long time to God's scourge, he made an offering of his free will to Him even late in the day as a gift which he had received as a part of his nature. For God deals with him by using reason, not power, so as not to undermine the freedom of choice which, by its very existence proves God the Creator to be opposed to the idea of destroying everyone; He threatens torment only to prevent Himself from finding someone whom He has to kill or to condemn to everlasting fire.

31. If Pharaoh's heart had been hardened in order to demonstrate only God's power, as the ungodly suppose, and not His mercy at the same time, then, once hardened, it ought surely never to have grown soft again as it had when he said to Moses: 'Go sacrifice to your Lord as you wish and pray to the Lord for me, that this plague may leave me and my people' (cf. Ex 8:8,28,etc.); nor would he have said: 'I have come to know that your Lord is just; but I and my people are wicked' (Ex 9:27). Can you not see in him a man publicly acknowledging his wickedness? He recognizes that he is being chastised as a result of a just judgment of God, and this is something which also Christians are seen doing very late in the day! And do you really believe that it was the God of mercy who had hardened Pharaoh's heart so that he might perish in his iniquity, that same God who said: 'I do not wish the death of the sinner but that he should turn and live' (Ezek 33:11); and: 'In that day when the wicked man turns from his iniquity and does penance none of his sins shall be held against him' (Ezek 12:14,16)? As has often been stated, He said that He would harden Pharaoh's heart so that he would be slower to release the people whom he had held in thrall and, thanks to this delay, the punishment of Egypt by the ten plagues would bring great joy to the Hebrew people and leave a great example for future generations of Egyptians to fear and benefit from. It would also leave a great and miraculous message of the extension of the power of the Church to be borne throughout the world. Through this message all the nations would recognize that their own gods were as nothing when confronted by the power of this God of ours, whose servant parted the sea with a touch of his rod and who also, as it is said, 'executed judgment on the gods Egypt' (Num 33:4). And so 
this God, who does not wish for the death of a sinner and does not make distinctions between individuals, however stern this correction may seem to be, always administers it in such a way that by His blows He may bring to know Him men who were previously far removed from His presence. Had this not been the method which he adopted, Pharaoh would never have come to recognize God as the Maker of heaven and earth, as he did when he said, 'I have come to know that God is just and I am evil', though he had previously said, 'I do not know God' (Ex 5:2), before his punishment. Perhaps it will be of some avail to him in the Day of Judgment to have had to endure the scourges of God.

32. The scriptures provide us with a similar case in that of the blessed Job: though righteous according to God's own testimony, it is nevertheless clear that it was by being chastised that he was led to the true knowledge and sight of God. And if someone is moved by Pharaoh's case, he must realize that both men, the most righteous Job and the most ungodly Pharaoh, were brought to the same furnace and given a dose of the same medicine by the same artificer; in fact, Pharaoh, as befitted one who was weak, was treated more charitably than the blessed Job, seeing that the latter was in all respects the stronger of the two. For if you listen to God saying, 'I will harden Pharaoh's heart', with the ear of the inner man and if you know the religion of the Egyptians, you will find it impossible to misunderstand the manner in which his heart was hardened, especially when you recognize that Pharaoh worshipped and revered gods made of clay. Through worshipping gods of this kind with all his heart, he was turned in his own mind into what he believed to be a god and worshipped as such, that is, a god of earth and clay, the substances of which his gods were made. Everyone then, who does not know the God of heaven, is himself of earth and clay, and over his head is to be found that saying of the Holy Spirit which was uttered through the lips of the prophet: 'Let them become like those who make them and those who trust in them' (Ps 115:8), meaning earth and clay. So God foresaw that Pharaoh's heart would be moved towards the fire of tribulations in the course of the liberation of Israel and, having been moved towards it, would be hardened by the fire, since he was no more than clay; that is why He said that he would harden the heart of Pharaoh and his servants. But because it was just for an innocent people, mindful of the God its fathers, to be 
delivered from the hands of the ungodly, He announced the outcome in advance as God.

33. But the righteous person, who is compared to gold, although he originates in earthy substance just as the ungodly man does, yet, by believing in the God of heaven and placing his hopes in him with all his heart, is transformed into gold to be stored in the treasuries of heaven. As bronze, when moved towards the fire of tribulation, is not only not hardened but becomes soft and sensitive to the artificer's hand, since it realizes that it is to its own advantage to be corrected, not smashed, by the hammer of the man who is beating it into shape. As Solomon declares: 'As fire tries gold, so the righteous man is tried in the furnace of tribulation' (Prov 17:3); and: 'As gold in the furnace He has tried them' (Wisd 3:6); and again: 'But the ungodly man, when he reaches the depth of evil, abandons all hope' (Prov 18:3). This is what we are shown happening to the Pharaoh of whom we have spoken above: not only God but two other agents are also said to have hardened his heart at the same time; when we are told, 'I will harden', it is God who is speaking; but, in the second case, 'Pharaoh hardened his heart and refused to let the people go'; and, thirdly, 'Pharaoh's heart was hardened' - by whom he does not tell us but we may infer that it was by the devil. We can now leave it to the discretion of the sensible reader or listener to decide to which of these three agents we are to ascribe the malicious and destructive intention of the one responsible for the hardening.

Honourable and dishonourable vessels

34. It remains to attempt with the greater knowledge revealed to us by the Lord an enquiry into the question posed to us regarding clean and unclean vessels, that is, vessels that are made for honour and vessels that are made for dishonour - how and by whom one vessel, according to Paul, is made honourable and another dishonourable. First, let us fix firmly in our minds as the anchor of our belief the fact that God wishes no one's destruction and that He has created no one who is not in His own likeness. Everything obscure and hidden from our senses then becomes clear through the revelation of the Lord. 
How could the scripture of the Old and New Testaments possibly fail to be in agreement with each other, when they have been revealed by God through one and the same Holy Spirit? Or the teachings of the gospels and the apostles be inconsistent with those of the patriarchs and prophets, when it is rather a case of the words of the patriarchs and prophets being reinforced by those of the gospels and the apostles? Nor is it at all credible that these men should have put forward views which are in conflict with each other or that in some passages statements which seem to contradict the most unambiguous of texts are to be understood literally. Surely these men were sent by the same God to reveal the light of knowledge to the whole world and, by persuading all unbelievers to lead them out from the cavern of their unbelief into the light of divine knowledge, seeing that they were all of the same spirit. From this we may derive the firm conclusion that the blessed Paul, in the passage in which he says: 'So then He has mercy on the one on whom He wishes to have mercy and hardens the man whom He wishes to harden' (Rom 9:18) is not giving his own opinion but that of an imaginary opponent and, as has been said before, is behaving like a great orator when he himself both advances and explains for the sake of pious enquirers objections which he foresaw could be advanced by his adversaries. For if it is believed that this was Paul's perception of the good God - God forbid! -, how can he himself say: 'I have become all things to all men so that I may win them all over' (1 Cor 9:19.22), and 'God has made all things prisoners of sin so that He may have pity on them all' (Rom 11:32)? In other words, He found no one in this world who was not in need of His mercy and to whom the gifts of His deliverance would not be imported by 'the man Christ Jesus, the one mediator between God and men, who gave Himself as a ransom for all and who desires all men to be saved and to come to the knowledge of the truth' (1 Tim 2:5.6). But, as we said at the outset, all texts can be understood correctly and a true catholic sense as being compatible with each other, if you but visualize the Divine Law as having many different members, just as one individual has, some of them luminous and comparable to eyes, others hidden in the inner parts, and so those which are in obscurity must be brought out into the open and explained in a sense which is clear and needs no interpreter. And once this correction has been made by applying the rule of our faith we are able 
to grasp the sense in which Paul said: God has mercy on the man on whom He wishes to have mercy and hardens the man whom He wishes to harden.

35. The judgment of the man who says, 'Therefore He gives this and that to whomsoever he wishes' is assuredly true. But let us ask, 'What kind of will has God, who is good? Is it good or evil? Is it comparable to the will of men?' No one in his right mind will dare to assert that God has an evil will or that the will of the most high God is comparable to that of men, when He who is Himself in the bosom of the Father testifies that there is no one who is good by nature save God only. And what kind of will are we to suppose one who is good to have except the kind which He Himself is by nature? Look at Christ, the Son of God, than whom no one is greater, no one wiser, in whose will reside the knowledge and will of God the Father; it is He who proves to us that the good God possesses a good will because He is good! Look at our God, that is, Christ's God, proved to be good because He wills only good things! Let those who assert that God does not wish all men to be saved produce another God who can fit in better with our mad ideas! Since, therefore, God's will is proved to be good, we know that it is because of their previous good or evil deeds that men take in their hands either the cup of mercy with Adam, the first man, who sinned after having been deceived by another, or the cup of hardening with the devil, who was changed into evil not because he was deceived by another but because he persisted in obeying his own will. For God has mercy on the man whose heart $\mathrm{He}$ approaches but hardens the man from whose heart $\mathrm{He}$ has withdrawn Himself on account of his previous misdeeds. This is the principle established by Paul, when he says, 'He has mercy on the man on whom He wishes to have mercy and hardens the man whom He wishes to harden'. Without doubt there is only one kind of hardening, and it is God's withdrawal far away from the heart of the man from whom He recoils in horror as the devil's friend, which he has become by exercising his own will, as the prophet says of Esau and Jacob and Paul confirms: 'I loved Jacob but Esau I hated' (Rom 9:13; cf. Mal 1:3).

36. In this passage, then, the blessed Paul, like a good orator, has made up for himself a question for another to put to him. 'If,' he says, 'God is the Creator of human nature and makes no distinction between individuals and if, according to the prophet Ezekiel, 'The death of a wicked man does not result 
from the exercise of His will' (cf. Mt 18:14), then why, having loved Jacob, does He hate Esau? Why harden the hearts of Pharaoh and his servants when Israel has been set free, and thus kill as unjust a man whose heart He Himself is hardening? He could have shown compassion for Israel by setting it free without hardening Pharaoh's heart, removing the obstacle to its release instead and putting His mercy into effect in that way. Yes, He could have shown mercy for the people of Israel without hardening Pharaoh's heart; but, as we have said, the apostle rejects that possibility, assuming the role of a man who wishes to enter the palace of knowledge without the illumination of belief, and when the man tries to discuss the question in a spirit of arrogance rather than out of a desire to learn, he replies to him: Who are you, man, to answer back to God? Then you say to me, 'What does He still require of us?' For 'who can resist his will' (Rom 9:19)? Especially as His will is exceeding good and clearly prevails over all His other powers?

37. It is against this good will that the devil fights daily in the hope of turning it from goodness into savageness, and that is why he forces men to sin. But God's will daily receives the penitent into His care, since it cannot be overcome. If God's good will did not prevail over all His other powers, the world along with all its innocent inhabitants would have been condemned by His foresight alone before it was ever made, there would never have been an opportunity for the wicked to repent, and the number of the righteous would have suffered a great loss as a result. And so the blessed apostle Paul teaches us that no one can resist God's will, which, acting in opposition to His foresight, justice and power, was alone able to ensure that he would prefer many thousands of wicked men to continue to exist for the sake of a small number of righteous men, and that despite the opposition and, so to speak, loud protests of His foresight, which knew, before man was created, that he would be the source of many evil deeds. God's good will could not be overcome even by His foresight, so that He might have someone on whom to bestow the riches of His goodness by welcoming the penitent and making them righteous. For the Holy Spirit taught us through Solomon that nature and extent of God's goodness, comparing the church's beauty to good will's comeliness: 'You are wholly beautiful, my nearest one, wholly comely, like good will' (Cant 6:4). What could good will possibly be, and to whom could it possibly belong except God 
alone, the only one who is good by nature? And men too have good will, it is from Him who owes His existence to no one that they have received it. And what else can we understand His will to be except compassion, which the prophet acknowledged to be the peak of all virtues when he said: 'And His mercy extends over all His works' (Ps 145:9)?

38. Having shut the door on the arrogant fellow whose role he assumes here and to whom he is seen to be replying, he then opened it wide to pious enquirers by saying, 'What does He still require of us?' That is to say, 'If, without making any distinctions between good and bad deeds committed in the past, 'God has mercy on the man on whom He wishes to have mercy and hardens the one whom He wishes to harden' and then kills the latter in consequence, 'Why does He still find fault?' How can you carry out God's command to 'love the Lord your God with all your heart'? How can we renounce the world and follow in Christ's footsteps to heaven? How meditate on the Law of the Lord day and night? How love our enemies and do good to those who hate us? Without any doubt all these things will come to an end if the sentence 'God has mercy on the man on whom He wishes to have mercy and hardens the man whom He wishes to harden' is understood literally. But, in fact, as we have often said, these words are uttered by an arrogant teacher who lacks the illumination that comes from belief and discusses the works and the will of the Lord like a blind man - the kind of fellow to whom the prophet says: 'If you do not believe, you will not understand' (Isa 7:9). Doubtless it was to such a man that the apostle is replying when he says, 'But who are you, man, to answer back to God? Does the mould say to its moulder "Why did you make me like this?"' (Rom 9:20). If the words were not spoken by an arrogant busybody, Paul would not say, 'Who are you, man, to answer back to God?' Surely, by showing him to be an inquisitive and wrongheaded fellow, interfering in something which is not his business, Paul makes it clear that he is being refuted as one who has not yet got to know his Creator as he ought to have done; he presumes to pass such a rash, impetuous judgment on God's work, that he deserves a riposte of this kind for not having yet taken the trouble himself to adorn the lodging of his own heart with good works and so make it a place where the Holy Spirit - of whom Solomon said: 'The artificer of all things has taught me understanding' (Wisd 7:22) - may enter in and reveal all 
His secrets. To a man such as this, then, a man who does not understand heavenly things, who does not know of the existence of a spiritual law, a man who is bereft of religion, the apostle replies, 'Who are you, man, to answer back to God?' Such a fellow, though no different from mud himself, passes his life in love with the earth and has not heard the command: 'Be still and know that I am God' (Ps 46:10).

39. He dared to murmur against the potter asking, 'Why, if every single individual human nature consists of the same flesh, would God have made one into a vessel of honour with the splendour of his riches, the other however into a vessel of dishonour with the rot of poverty?' Similarly some have dared to blather against the Lord asking, 'Why would he have made one man an emperor, another man a common soldier?' 'If God,' so they say, 'makes no distinction between individuals, why does he make one man a bishop of the highest order, another man the servant of a bishop? One man a goldsmith, who works precious stones and makes golden embroideries of the kind which Beleseel was told to produce for the Holiest of The Holies (Ex 31:2ff.), another one a cutter of bricks from rock or timber? One with delicate and supple hands, proceeding in golden robes, and touching the dust of the earth only with utter disdain, the other one with dirty hands, dressed in rags, tilling the soil with hoe and spew, his feet in chains? It is to them, as already mentioned, who arrogantly scrutinize such differences asking why the potter should have created such a variety of destinies, that the apostle responds: 'Who are you, man, to answer back to God?' Thus he uses pottery as an example. For as a piece of pottery cannot protest to whoever is its potter to be made, for example, a great platter rather than a little urn, so it is with someone who arrogantly and angrily complains about being poor or not being in power, whatever would seem to such a man to make him a vessel of honour. The apostle has put an end to such complaining against the potter by distinguishing between earthly honour on one hand and heavenly honour on the other. And for someone who may well seem to be a vessel of dishonour in the body by being in a condition of poverty and servitude, compared to others who may seem to glitter in golden garments and riches, that earthly condition may nevertheless not take away his heavenly honour. And without making its maker sad a vessel of dishonour is made into a vessel of honour. This, therefore, is the way in which the potter is thought 
humanely to make 'one into a vessel of honour, another one into a vessel of dishonour.' It is only in order to meet the necessities of the world that one is cleaning out excrements from the sewers, while another one reclines in his litter and is held in highest esteem. And this is the reason why Paul, in the manner of a teacher, seems to want to warn the sons of the church with the example of the potter, so that someone who sees himself as a vessel of honour may not extol himself or, alternatively, become depressed and angry because he may start thinking of himself, according to what was said above, as a vessel of dishonour, since God has the power to 'exalt the lowly', that is, to make an honourable vessel, and to 'abuse the proud' by turning him into a vessel for dishonour before our eyes (Ezek 22:26; cf. Lk 1:52; 14:11).

40. On the principle by virtue of which we have been created to exercise freedom of choice everyone makes himself a vessel for honour or dishonour according to whether he becomes a vehicle for the Holy Spirit by his good works or carries the devil enclosed within him through his bad deeds. History demonstrates this fact in the case of Saul, King of Israel: so long as God lived in his heart, he remained a vessel for honour by keeping His commandments; but when by his unwarranted hatred of David he opened the door for the devil to enter his free will, he became a vessel for dishonour in which the devil could make merry, as the scripture shows: 'The Spirit of the Lord, it says, departed from Saul, and an evil spirit stifled him' (1Sam 16:14), meaning the devil. Likewise Jeroboam, King of Israel, was also a vessel of honour when he received from God by the hand of the prophet the kingship over the ten tribes of Israel but then, when he put his faith in idols and made golden calves, he became a vessel for dishonour for having taken the devil and his idols into his heart (cf. 1Kings 11:29ff.; 12:20,26ff.; 13). His disobedience then infected the people of Israel as a whole, and the History of Kings laments this for a period of many years: 'And the anger of the Lord,' it says, 'has not been turned away from Israel, because of Jeroboam, King of Israel, who made Israel sin' (cf. 1Kings 14:16,17; 15:34). Likewise we are told how Manasseh, King of Judah, by deserting the God of his fathers, worshipping at pagan shrines and erecting altars to evil spirits in God's sanctuary, became a vessel for dishonour (cf. 2Kings 21:1ff.; 2Chron 33:2). His vessel's smell was so repugnant to God that we read that He cast him out of his house in Israel into the furnace of the city of 
Babylon. There, shut up in a cave as if in a crucible, he is said to have been so purified of all the dross of all his sins and washed so thoroughly by his floods of tears that the was transformed into a vessel for honour again, worthy to be brought back to the house of God, that is, the land of Israel and to be a vessel for honour, as the History of Chronicles tells us, saying that, after repentance, he was restored to the kingdom of his fathers and recalled to God's friendship (cf. 2Chron 33:11ff.). Likewise in the case of David also: he would have become a vessel for dishonour instead of honour for improperly enjoying another man's wife, had he not cleansed the innermost parts of his heart of sin with the scraper of expiation. Then the Holy Spirit, which had fled from the stench of his sin, reentered him to make him a vessel of honour instead of dishonour. As he himself exclaims in the fiftieth Psalm: 'Renew a right spirit in my inmost parts; take not your Holy Spirit from me' (Ps 51:10,11).

41. See how the Moulder of clay, that is, God, who is our Maker, has the power to make one vessel for honour, another for dishonour. As long as a man has God living in him because of his holy conduct, he is a vessel for honour; but, as soon as he acts contrary to God's will, and the Holy Spirit deserts him, his heart is emptied of all holiness. Then, as soon as the unclean spirit finds it empty, it fills it with every kind of filth by its own actions, and of its victim the Saviour says: 'And the last state of that man will be worse than the first' (Mt 12:45). These words leave us in no doubt that God, when He leaves the heart of a man who deserves to be kept at a distance from Him, makes him a vessel for dishonour. But He transforms a dishonourable vessel into an honourable one when He receives penitents back again and cleanses their unclean hearts by His visitation. Thus God has the power to make vessels both honourable and dishonourable: located as they are in one and the same flesh and in one and the same Church, one man, by virtue of God's friendship for him and the occurrence of good works of his own, drives the evil spirits out of the parts which are being worked on by them, the other, because of God's withdrawal, is filled with the evil spirit which works like a scourge to test or punish him. Or does it not seem to you that the Holy Spirit, by merely speaking of an honourable vessel, drives the devil in terror from the dishonourable one? For to what man in his right senses would it not be obvious that it is evidently the vessel for honour which is the one from which the Holy Spirit is heard ordering 
out the demons, and the vessel for dishonour the one from which the devil is heard exhaling his breath? And what else but a dishonourable vessel does a man appear to be when he is full of the devil and pours blasphemies, falsehoods, obscenities and outright lies from his lips? What else but a dishonourable vessel do you believe a man to be when he holds the devil, persistent as ever, in his heart in bonds of friendship through his foul deeds, while the devil himself for his part holds on firmly with his net to the prisoner who is holding on to him? Without doubt everyone becomes a vessel of honour or dishonour as a result of his own negligence or astuteness and prepares himself either for eternal life by obeying God or for everlasting destruction by obeying the devil.

42. On this subject of vessels the apostle has explained that two kinds have been made out of one substance: vessels of wrath, in which, he says, the wrath of God is shown, and vessels of mercy, in which the riches of His glory, that is, His goodness, are revealed. He went on to state that the moulder of clay 'makes known the power which He has to make one a vessel for honour and another for dishonour' (cf. Rom 9:21,22). 'But what if God,' he says, 'desiring to show his anger' - not really His anger, since He is manifestly without passion and injustice, but that of those vessels which have accumulated within themselves the anger which was hidden from all, so that what had been concealed was now made clear to men - 'and to make known His power' (Rom 9:22) - as in the case of the Egyptians, of whose evil the world would have been ignorant if God had not made His power known in the liberation of Israel. Look at what Paul says about vessels of wrath, earlier described as 'vessels of dishonour': 'He has endured them,' he says, 'with much patience' (ibid.). And whom has He endured? 'The vessels of wrath made for destruction.' You may be certain that it is Pharaoh or one of his likes who is being discussed in this passage. He also goes on to explain why 'He has endured them with much patience': 'To reveal the riches of His glory (ibid. 23), that is, the power of His signs and wonders, a reminder to demonstrate His mercy. And though that mercy of His is universal, He has indicated those whom it is intended to profit: 'The vessels of mercy,' he says, 'which He has prepared beforehand for glory' (ibid.).

43. And so that you may not perhaps suppose that to achieve this end He has made distinctions between individuals in preparing the vessels, Paul added: 'Since he called even us not only from the Jews but also from the Gentiles' 
(ibid. 24). This text proves that there is no one whom He has not called or of whom He has made an exception, as He himself proclaims through the prophet: 'Hear this, all peoples! Give ear, all inhabitants of the world' (Ps 49:1). Thus we are taught beyond all doubt that $\mathrm{He}$ wishes to save all of the earth's inhabitants, since it is to all that $\mathrm{He}$ has given the commandments to be observed in their lives. For it is indeed the same voice of prophecy that brings God's commands to Pharaoh and which speaks to Nineveh as follows: 'Thus says the Lord, "Let my first-born Israel go; otherwise I shall smite your firstborn" (cf. Ex 11:4-6); and: Thus says the Lord of Israel, "If you hearken to the voice of the Lord God and do all that He commands you, you shall not be shaken" (John 15:14; 3:2-10),' and other words to this effect.

44. God, then, who is our Potter, has the power to make of His creatures what he likes. But the power of so great an artificer manifestly does not itself exceed the limits of justice in dealing with the vessels named and mentioned above: in the one case justice is observed, in the other mercy is shown. This means that in the case of those who have prepared themselves for destruction by practising evil God's justice undoubtedly reveals His anger, that is, His desire for vengeance. In their case, if God's desire for vengeance - which is what is understood by the apostle's word 'anger' - were not revealed, then the innocent people of Israel would still be imprisoned in the dungeons of Egypt by the impious Pharaoh, awaiting death brought on by their hard labour. This is undoubtedly the sense in which we should understand that God 'shows his anger': He exacts vengeance from the ungodly and by this means 'makes known his power' by freeing an innocent people from great dangers. And so the blessed Paul, foreknowing that human curiosity roams this way and that over many questions, like the great teacher and doctor of souls that he was, covered the general situation of all men, good and evil, by citing two different cases, that is the liberations of the people of Israel and the destruction of Pharaoh. If, in the case of Pharaoh, he had not exposed the anger which was hidden within that man and which he had accumulated within himself by his slaughter of the Israelites' babies, then the humble would still not have known God as a merciful Judge nor the ungodly as a powerful one. God in His mercy wished to save, not to destroy, the ungodly man and clearly it was for that reason that $\mathrm{He}$ gave him three draughts of medicine to cure him: these were, as the apostle tells 
us, His patience in enduring his cruelty, His anger in frightening him into letting go those whom he wrongfully held capture, and His power in turning the sea into dry land. In this way, even if Pharaoh had no respect for God's people, he would still refrain from pursuing them for all that, as soon as he saw that the element of water was at their service. But because of his stubbornness and unrepentant heart it was necessary for him to come to recognize God's power by dying, having experienced His patience while alive. As Paul himself says, 'He endures with great patience' (Rom 9:22)., that is, He endured with the same patience with which, he says, 'He endured the vessels of wrath made for destruction (ibid.). If it was He himself who predestined and prepared them for destruction and not the vessels themselves in agreement with the devil, the apostle would never be teaching us that the Lord 'endured them with great patience'. But, sweeping aside all the misgivings of the irreverent, he demonstrates that God was far from wanting to destroy sinners and teachers that, on the contrary, He 'endures the ungodly will great patience', so that they may repent. As the blessed Paul himself shows: He has endured with great patience the vessels of wrath made for destruction in order to reveal the riches of His glory for the vessels of many whom God has prepared beforehand for His glory (ibid. 22, 23).

45. He has also taught us in what the preparation of vessels consists, saying: 'He has called even us not only from the Jews but also from the Gentiles (ibid. $24)$; and informing us that the preparation of the vessels is revealed in their calling. 'The vessels of mercy prepared for the glory of God' are to be understood as those from Israel who were first to be filled with that Holy Spirit of mercy of which God is known to be full, and through them it has been poured into all believers. But if the 'vessels of wrath' who had prepared themselves for destruction, that is, the Egyptian unbelievers, had not perished, what reason would there be for those who are the recipients of God's mercy to believe in His wonderful works? Their faith, which would enable them to recognize the God of heaven as their sole liberator, would still be fragile up to this day. Surely the death of the ungodly has made a proven contribution to the great progress of the righteous, as this text in Exodus witnesses: 'The children of Israel,' it says, 'saw the Egyptians dead and believed in God and in Moses, his servant' (Ex 14:31). If the ungodly man had not perished when Moses' 
prophecy foretold that he would perish for his ungodliness, how could they have continued to believe in the prophets who had foretold that Christ would come to redeem the world? For it was from the time of Pharaoh's death that the life of humanity began to shine forth, and it was from those who were set free from his clutches that the prophets, the apostles and even Christ Himself, the Redeemer of all - in His bodily form of course - originated. Certainly faith is known to be a great cleanser of the soul, by which all the poison of $\sin$ is forced out of our hearts. By this means a dishonourable vessel may be converted into an honourable one, just as the blessed Paul himself was on his own testimony: 'I was formerly a blasphemer and one who insulted Him' (1 Tim 1:13).

46. In his discussion of honourable vessels he did not exclude the dishonourable but taught that both sorts were needed in a great house, the one for work, the other for other purposes, as the Lord laid down: 'In a great house,' he says to Timothy, there are not only vessels of gold and silver but also vessels of wood and earthenware, some for honour and others for dishonour' ( 2 Tim $2: 20)$. In this way he instructs us that vessels have grades and orders appointed for them according to the daily needs which they have to supply; nevertheless, in regard to merits he has not reserved a special category for splendid vessels made of gold or silver but has opened it to each and every man according to his potential even when he continues in his own order. If this man lacks the ability to rise to higher places, it is sufficient for him to keep the commandments which he has received, as the apostle himself lays down when he says: 'A brother should remain in the calling to which he has been called before God' (1Cor 7:20). 'If you are a servant,' he goes on - and this is what a vessel for dishonour is considered to be - 'make even greater use of God's commandments' (cf. 1Col 7:21). By this means you may be made free as far as your human state is concerned, for it is in this that the whole essence of freedom consists, and you should not care too much about your present servitude, as long as you are rich in heavenly freedom.

47. This is how Paul himself makes use of God's commandments when he says: 'For though I am free of all masters, I have made myself a slave to all in order that I may make all free through Christ' (1Cor 9:19). Trusting in his Lord's mercy, he makes no distinction between the different kinds of vessel that he is leading into His house, remarking of some of them: 'What they have been 
at one time or another makes no difference to me; for God does not make distinction between individuals' (Gal 2:6). And although he himself was an elected vessel of great value, he chose to give his own life for dishonourable vessels if possible but only to ensure that his Lord's house would be packed full with a great number of vessels of different kinds. When he said, 'I would be willing to become an "outcast from Christ" (Rom 9:3) for the sake of my brethren who are Israelites, that I might win them over,' he did so not because he really wanted to become an 'outcast from Christ', when Christ was his very life, but so that one may recognize in a servant that goodness which you cannot doubt in his master. His Master wanted no one to perish and wept, rather than rejoiced at the destruction of the living; He, the Redeemer Himself, bears witness to this with a solemn oath: 'In God's truth I say to you that whosoever lives and believes in me shall never die but shall pass over from death into life' (John 3:16; cf. 10:28); and, through the prophet Ezekiel: 'As I live, says the Lord, be sure that I have no wish for the death of a wicked man but rather that he should turn from his evil way and live' (Ezek 18:23).

48. If then anyone is grieved that he has made a dishonourable vessel for reasons stated earlier, that is because he is soiled by the dirt of human servitude or servitude to sin - in accordance with the saying, 'Everyone who sins is a slave to sin' (cf. Prov 5:22) - let him not be slow to listen to our teacher's words: 'If anyone purifies himself from these things, he will be an honourable vessel' (2Tim 2:21), that is, if he frees himself of the disgraceful practices and deeds which the Lord curses and on account of which, though fashioned by His Maker for honour, he has made himself a dishonourable vessel by deviating from God's commandments of his own choice. But now, by exhaling the evil from the vessel from which the Lord pours the example of His own sanctity into other vessels. For our teacher, the apostle, in order to instruct us thoroughly and with certainty that grades of honour are not based on partiality for individuals but on the extent to which we cling to God's love, puts it into words which leave no room for doubt: 'If any man has served well,' he says, 'he gains a good standing for himself and great confidence in God's sight' (1Tim 3:13); and in order to confirm with even greater precision the fact that the whole essence of perfection depends on the Creator's love rather than predestination, he substantiates this by saying: 'We know that everything works together for good 
for those who love God' (cf. Rom 8:28), meaning wealth and poverty, material gain and loss, fecundity and privation of children, sadness and joy, sickness and health, life and death, all work together for good for those who love God with all their heart. This was confirmed in the case of the blessed Job, whom no loss of existing goods could tear away from his love of God. And in case it might perhaps be asked why such things do not turn out well for everyone, the apostle also taught us that what is required is right intention of mind, which is ingrafted in our nature, that same intention about which the angels cry at the time of the Redeemer's birth: 'Peace on earth to men of good will' (Lk 2:14). He went on to explain who could profit by such co-operation in goodness: 'Those called according to His purpose' (Rom 8:28). It is manifest that, in fact, all have been so called, according to the prophet David: 'Hear this, all peoples' (Ps 49:1); and: 'Praise the Lord, all nations! Extol him, all peoples' (Ps 117:1); and 'Make a joyful noise to God, all the earth' (Ps 66:1).

The call of the elect

49. But a call of this kind can benefit only those who, in accordance with the intention of their good will, have come to Him who calls them and, coming, have answered and persevered in their calling. Undoubtedly they are the ones who truly love God, who, whether they have been placed in prosperity or adversity, never distress God their Creator, by turning away from Him but always remain the same; who are poor in terms of worldly riches but rejoice in that poverty; who give thanks when in sound health but glory in bodily weakness; who, while deeming it necessary to live, yet consider death to be a great gain. Clearly it is of them that the apostle is speaking when he teaches us: 'Those whom He foreknew He also predestined to be formed in the likeness of His son, that He might be the first-born among many brethren. And those whom He predestined He also called; and those whom He called He also justified; and those whom he justified He also glorified' (Rom 8:29.30). These are indeed the ones of whom God knew that they would not love only with their lips, would not follow in Christ's footsteps only for a while and then desert Him when troubles arose but would cling to His love with all their heart and with all their 
soul and with all their strength 'in troubles, in distress, in danger, in hunger and thirst, in cold and nakedness' (2Cor 6:4), would endure with Him to the end and never be parted from Him. On this subject the Saviour bears witness for them: 'To you,' He says, 'I speak as my friends, who have continued with me in my troubles' (Lk 22:28). These then are the ones who were foreknown and predestinated to die and live with Christ: of whom it was also foreknown that they would love God with a true, not a feigned love; all of whose adversities were turned into good; who were called according to the intention of their will; who were predestined to be shaped in Christ' likeness when preaching the remedies required to save human nature; to whom He bequeathed the power to bind and loosen in this world in their appointed turn, just as they left their successors the responsibility of imitating them. And, of course, being shaped in Christ's likeness means that, in the same way as he said to the paralyzed man, 'Rise and walk' (Mt 9:5), so they too may say to the lame man, 'Rise and walk'. It was these men who presented themselves when called: they did not contrive any excuse for delay, they sought no bodily comfort, they were not called back from Christ's side by their attachment to any worldly bond. Thus they were called in person to the end that they might carry Christ's name to the Gentiles, 'making up themselves whatever is lacking in Christ's afflictions' (cf. Col 1:24); that is why they acquired the name of 'those who were sent', that is, 'the apostles' - and they were also named 'sons of thunder', that is, 'Boanerges' (Mk 3:17). They were 'called' by the words which they heard from the Lord's lips: 'Follow me, and I will make you fishers of men' (Mt 4:19). They were 'justified', a term which is understood in the sense that Christ vested such trust in them because of their obedience in all things that he made them friends instead of servants, saying: 'No longer will I call you servants but friends; for the servant does not know his Lord's will, but you do' (John 15:15).

50. These men were so attached to Christ by bonds of friendship that nothing, be it the power of kings, chains, prisons or cruel torture, could deflect them from the path of righteousness, as they themselves say in reply to the chief priests: 'It is righteous to obey God rather than man' (Acts 5:29). They were, therefore, elevated to such a peak of righteousness by expelling all the filthy water of unrighteousness from the vessel of their heart that Christ was able to accomplish far greater things through them than He is known to have done by 
His own efforts, as He Himself says: 'You will do greater things than these' (John 14:12). For they were so full of the Holy Spirit, their leader in righteousness, that, like stubble at the touch of a flame, all the evil of unrighteousness was consumed in their path. This is what happened in the matter of the treachery of Simon the magician, all of whose unrighteousness was consumed on the arrival of Peter and John in Samaria (cf. Acts 8:9-24); or when Ananias and Sapphira were put to death for their deceit and unrighteousness by the utterance of only one word by Peter, on fire as he was with the flame of the Holy Spirit (cf. Acts 5:1-11), or when that magician who tried to divert the proconsul from the path of faith is reported to have been wounded by the hammer of blindness, directed at him by the righteousness that worked through Paul, and, as proof of this, we have the authority of the History of the Acts of the Apostles (Acts 13:8-12). Note how they were 'foreknown', 'predestined' and 'called according to the intention of their mind' and so, through their teaching, reached the splendid maturity of Christ's full stature and became great men. It was for this, then, that they were 'magnified' and approved, since, we are informed, whatever they taught they had practiced beforehand, as the Lord testifies in the gospel: 'He who acts and teaches men in this way shall be called great in the kingdom of heaven' (Mt 5:19).

51: These then are the ones who were shaped in the likeness of Christ spoken of above and foreknown, predestined, called and justified, so that they might become like Christ in all respects to die and to live with Him who foreknew that, through their strength of mind they would endure to the end all that they suffered for His name's sake and yet remain immovable - 'to make up what was lacking in Christ's afflictions' for the salvation of men. In return, by enduring with magnanimity the hardships and storms of persecution, they earned the right to be 'magnified' and, as we believe, will sit alone in their greatness on twelve thrones as judges with Christ, taking precedence over all others, according to His promise: 'You will sit on twelve thrones, judging the twelve tribes of Israel' (Mt 19:28). They are shown to have been 'magnified' because of their labours that, as the crowds marvelled at Christ, saying that 'a great prophet has arisen in Israel' (Lk 7:16), so they too were not only believed to be prophets by the Gentiles but gods by the Lycaonians (cf. Acts 14:11). The History of the Acts of the Apostles proves this to be true of Paul and Barnabas, 
whose righteous words opposed the wisdom of this world, that is, the bombast of the philosophers, the cruelty of the Jews and the madness of their persecutors, when they said: 'If God is for us, who is against us' (Rom 8:31).

52: The evil spirits showed great jealousy of them, these holy men who were being made great out of nothing, under their very eyes. The apostle, observing the way in which the evil spirits' savagery was daily being vented on the holy, fortified the resolve of his hearers by saying, 'If God is for us, who is against us?' And in case we may perhaps suppose that this protection benefits only those who have been 'foreknown, predestined, called, justified and magnified,' not everyone, that is to say, who believes in God and calls upon Him, he adds: 'Who did not spare His only son but gave Him up for us all' (ibid. 32), just as the prophet had said earlier: 'For everyone who calls upon the name of the Lord shall be saved' (Joel 2:32). To prevent anyone from doubting whether others can be associated with those mentioned above in their glory, having said, 'He gave Him up for us all,' he then added, 'Surely He gave us all things when $\mathrm{He}$ gave us Him?' (ibid.).

53: But if someone were to say that these gifts benefit only those who have been most shaped in the likeness of Christ in all respects - as men of perverted belief are in the habit of saying that 'God, if he so wishes, will be able to save all men' or 'honourable vessels are made but not dishonourable' whoever, I say under the guise of grace tries to introduce the dogma of fatalism, let him first consider carefully the view expressed by the blessed Paul on the question: For whom does he maintain that Christ died, the righteous or sinners? He will then discover whom the words spoken have benefited and how some are made dishonourable vessels. If then Christ died for the righteous, Paul ought not to have said: 'Christ died for the ungodly' (Rom 5:6). If God wishes to save only a part and not all of those whom He created in His own likeness, then, according to them, the apostle lied when he said: 'We must all stand up before the judgment seat of Christ, so that each one may receive either good or evil according to what he has done' (2 Cor 5:10); and: 'Whatever a man sows, that he will also reap; and he who sows in the Spirit will reap eternal life from the Spirit but he who sows in the flesh will reap corruption from the flesh' (Gal 6:8); and elsewhere he says: 'You have become the servants of him who you 
have obeyed, either of righteousness or of sin' (cf. Rom 6:16), in other words, to become an honourable or a dishonourable vessel.

54: But, to remove all possible suspicion that any evil intent is present in God, Paul represented himself as the foremost of all sinners, saying: 'Christ Jesus came into the world to save sinners, of whom I am the foremost' (1Tim 1:15). And, in order to make other men honourable, instead of dishonourable, vessels, he also admitted that he himself had once been a dishonourable vessel, when he said: 'I who formerly blasphemed and insulted Him but received mercy because I acted in ignorance and unbelief' (ibid. 13). This happened, he said, so that in him 'Christ might display His perfect patience as a model for those who were in future to believe in Him and come to eternal life' (ibid. 16). He instructed his hearers that they ought to become like him, just as he himself had become like Christ, and how they ought to do this, and exhorted them to 'be imitators of me, as I am of Christ' (1Cor 11:1). In the passage in which we see him debating with an arrogant opponent he has told us what the Potter does and has delivered what is acknowledged to be his definitive judgment. He has now carefully explained to his dearest son, Timothy, that it is for each of us to decide of our own free will which course we take, either to become an honourable vessel through good deeds and words or through evil deeds and unseemly talk to become a dishonurable vessel: if a man cleanses himself of these things, he will be a vessel of honour (2Tim 2:21). And he adds the names of the things of which one has to cleanse oneself: Shun youthful passions, he says, aim at righteousness, faith love and peace along with those who call upon the Lord from a pure heart and have nothing to do with foolish and ignorant controversies (ibid. 22, 23); for they lead only to godlessness (ibid. 16).

\section{Final exhortation}

55: And so it is by avoiding these things that dishonourable vessels are turned into honourable vessels and that those who formerly bore around with them the most offensive odour of the devil for the destruction of souls now carry that 'fragrance of the knowledge of Christ' (2Cor 2:14) which is to their profit. This is what the true record shows to have happened in the case of Paul 
himself, from whom such a fragrance of the teaching of salvation spread throughout the whole world that its inhabitants, who had by now sunk down almost into the pit of death, were led back again to eternal life by his doctrine: there is no corner of the world which has not been reached by the doctrine which he preached with Christ's assistance. In this way, by transferring the Lord's gifts to others, many of them like Pharaoh, he has clearly made them honourable, instead of dishonourable, vessels by his example and teaching. $\mathrm{He}$ himself bears witness to this when he says: 'Where evil multiplied there came a greater abundance of grace' (Rom 5:20). He it was who called on others to 'run the race', so that he might win them all over and then they might either be delivered from the jaws of the devil by their running or meet Christ, to meet whom is life itself, when he said: 'So run the race that you may all win the prize' (1Cor 9:24). 